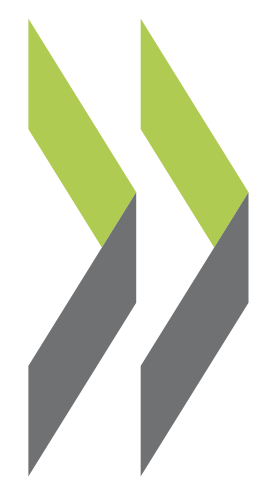

OECD Economics Department Working Papers No. 1582

\title{
Fostering strong and relevant skills in Iceland
}

\section{Vassiliki Koutsogeorgopoulou, Laura Brogi}




\section{ECONOMICS DEPARTMENT}

\section{FOSTERING STRONG AND RELEVANT SKILLS IN ICELAND}

ECONOMICS DEPARTMENT WORKING PAPERS No. 1582

By Vassiliki Koutsogeorgopoulou and Laura Brogi

OECD Working Papers should not be reported as representing the official views of the $O E C D$ or of its member countries. The opinions expressed and arguments employed are those of the author(s).

Authorised for publication by Isabell Koske, Deputy Director, Country Studies Branch, Economics Department

All Economics Department Working Papers are available at www.oecd.org/eco/workingpapers.

JT03455549 
OECD Working Papers should not be reported as representing the official views of the OECD or of its member countries. The opinions expressed and arguments employed are those of the author(s).

Working Papers describe preliminary results or research in progress by the author(s) and are published to stimulate discussion on a broad range of issues on which the OECD works.

Comments on Working Papers are welcomed, and may be sent to the Economics Department, OECD, 2 rue André-Pascal, 75775 Paris Cedex 16, France, or by e-mail to econ.contact@oecd.org.

All Economics Department Working Papers are available at www.oecd.org/eco/workingpapers.

On 25 May 2018, the OECD Council invited Colombia to become a Member. At the time of preparation the deposit of Colombia's instrument of accession to the OECD Convention was pending and therefore Colombia does not appear in the list of OECD Members and is not included in the OECD zone aggregates.

This document and any map included herein are without prejudice to the status of or sovereignty over any territory, to the delimitation of international frontiers and boundaries and to the name of any territory, city or area.

The statistical data for Israel are supplied by and under the responsibility of the relevant Israeli authorities. The use of such data by the OECD is without prejudice to the status of the Golan Heights, East Jerusalem and Israeli settlements in the West Bank under the terms of international law.

\section{(C) OECD (2019)}

You can copy, download or print OECD content for your own use, and you can include excerpts from OECD publications, databases and multimedia products in your own documents, presentations, blogs, websites and teaching materials, provided that suitable acknowledgment of OECD as source and copyright owner is given. All requests for commercial use and translation rights should be submitted to rights@oecd.org 


\section{ABSTRACT/RÉSUMÉ}

\section{Fostering strong and relevant skills in Iceland}

Strong and relevant skills are vital for helping Iceland to adjust to rapidly changing technology and competition in the world economy and safeguard high prosperity and wellbeing. Many students, especially those with an immigration background, lack solid core skills and competences that weakens the skills-base. Vocational and tertiary education do not always provide skills needed by the labour market. A comprehensive approach is required to strengthen skills, based on systematic assessment and forecasting exercises. This should include measures to improve teaching quality, including through stronger professional development, and ensure its equitable distribution; strengthen the work-based component of vocational training; and ensure that tertiary education provides the right skills. Beyond education, effective re-skilling and up-skilling programmes, including for immigrant workers, and strong work incentives are essential for further skill development and to help make the best use of existing skills.

This Working Paper relates to the 2019 OECD Economic Survey of Iceland

http://www.oecd.org/economy/iceland-economic-snapshot/

JEL classification codes: I20, I24, I28, J15, J24

Keywords: Iceland, education, immigrants, work incentives, lifelong learning, mismatch, professional development, skills, vocational education and training

\section{Favoriser des compétences solides et pertinentes en Islande}

Des compétences solides et pertinentes sont essentielles pour aider l'Islande à s'adapter à l'évolution rapide des technologies et de la concurrence dans l'économie mondiale et à préserver une prospérité et un bien-être élevés. De nombreux étudiants, en particulier ceux issus de l'immigration, ne disposent pas de compétences de base solides ce qui affaiblit le socle de compétences. L'enseignement professionnel et supérieur n'offre pas toujours les compétences nécessaires au marché du travail. Une approche globale est nécessaire pour renforcer les compétences, sur la base d'exercices d'évaluation et de prévision systématiques. Cela devrait inclure des mesures visant à améliorer la qualité de l'enseignement, notamment par le biais d'un développement professionnel renforcé, et à assurer sa répartition équitable, à renforcer la composante professionnelle de la formation professionnelle et à garantir que l'enseignement supérieur offre les compétences appropriées. Au-delà de l'éducation, des programmes efficaces de recyclage et d'amélioration des compétences, y compris pour les travailleurs immigrés, et des incitations au travail efficaces sont indispensables au perfectionnement des compétences et permettent de tirer le meilleur parti des compétences existantes.

Ce Document de travail se rapporte à l'Étude économique de l'OCDE de l'Islande 2019

http://www.oecd.org/fr/economie/islande-en-un-coup-d-oeil/

Codes de classification JEL: I20, I24, I28, J15, J20, J24

Mots-clés : Islande, éducation, immigrants, incitations au travail, formation continue, inadéquation, développement professionnel, compétences, enseignement et formation professionnelle 


\section{Table of Contents}

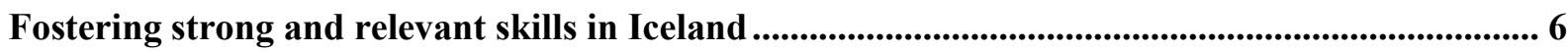

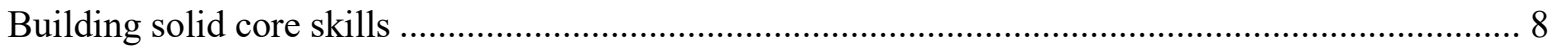

Iceland spends significantly on education but outcomes have deteriorated ................................... 8

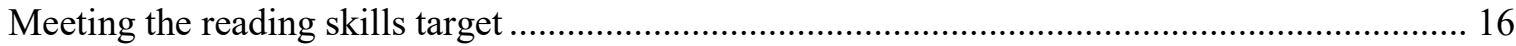

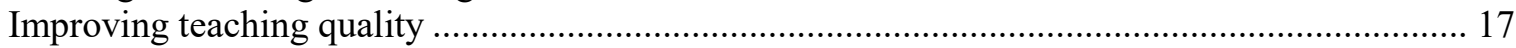

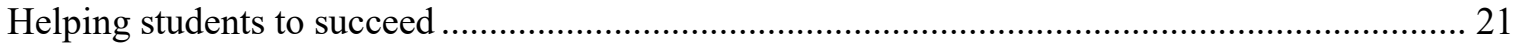

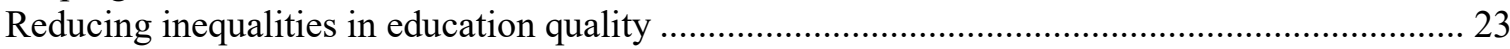

There is scope for better skills matching and a more rigorous analysis of skills needs ..................... 24

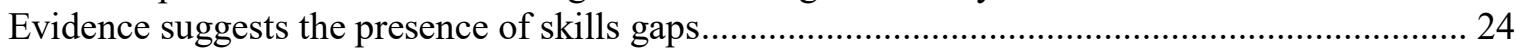

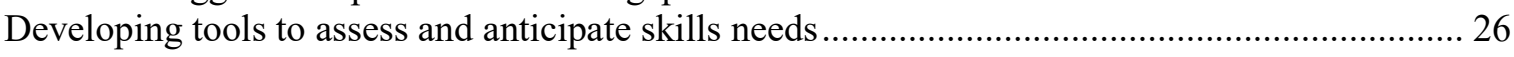

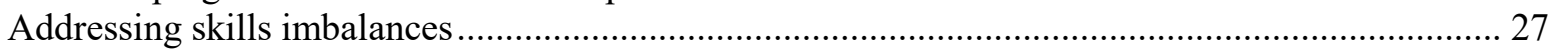

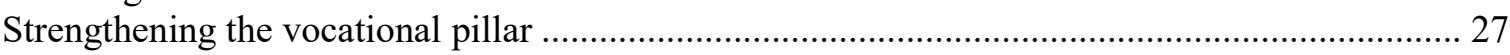

Harnessing skills for a knowledge- and innovation-driven economy ......................................... 30

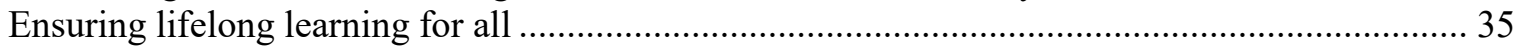

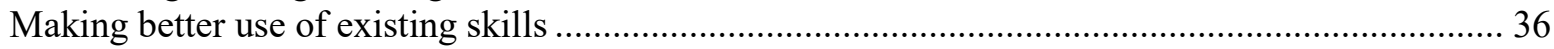

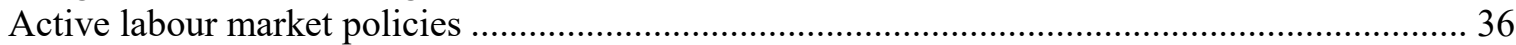

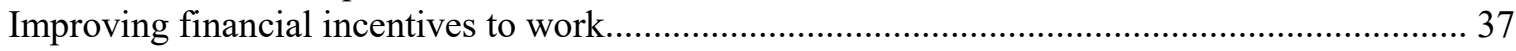

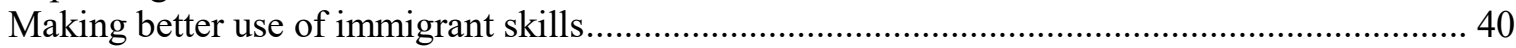

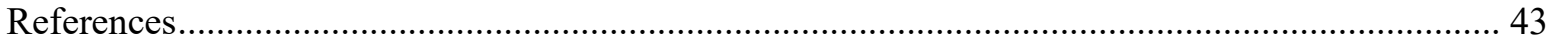

\section{Tables}

Table 1. Unemployment insurance benefit (UI) provisions in selected countries................................ 39

\section{Figures}

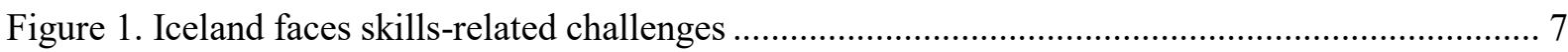

Figure 2. Iceland spends comparatively more on compulsory education............................................ 8

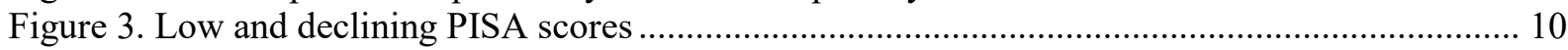

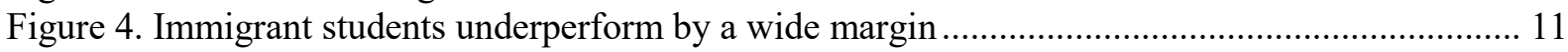

Figure 5. Socio-economic background has a small impact on students' outcomes.............................. 12

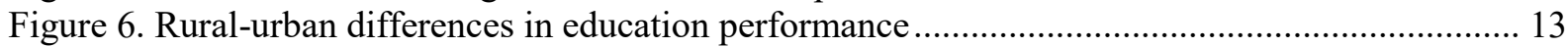

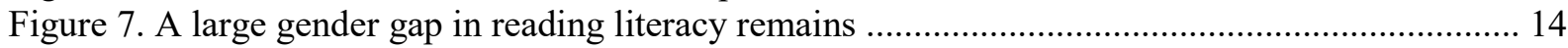

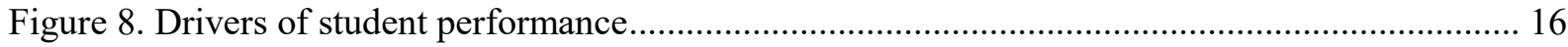

Figure 9. The teaching profession faces challenges at primary and lower secondary level ................. 18

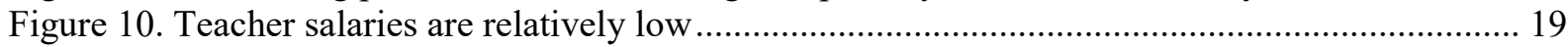

Figure 11. There is scope to improve teachers' training and professional development........................ 22

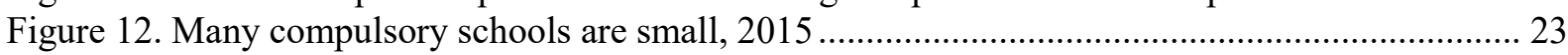

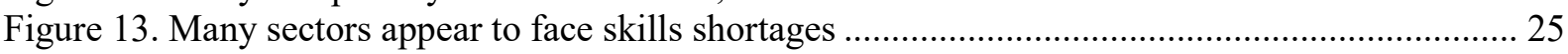

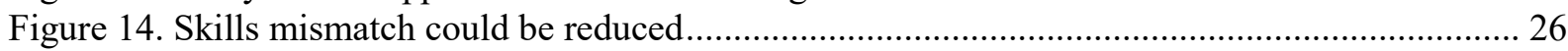

Figure 15. Participation in VET needs to increase, despite good job outcomes.................................... 28

Figure 16. School dropouts and late completions affect VET students more ...................................... 29

Figure 17. Tertiary education performance could be enhanced ...................................................... 31

Figure 18. Relatively few students graduate from STEM fields ....................................................... 33

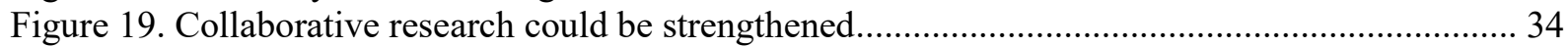




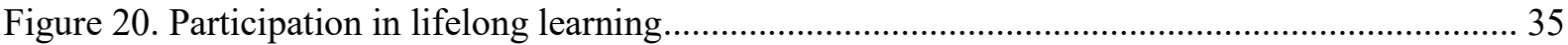

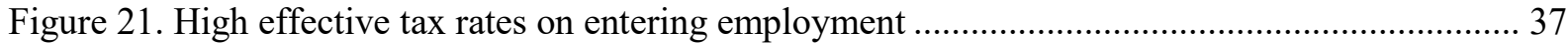

Figure 22. Relatively high net replacement rates may reduce work incentives ................................... 38

Figure 23. Immigrant integration in the labour market could be strengthened .................................... 41

\section{Boxes}

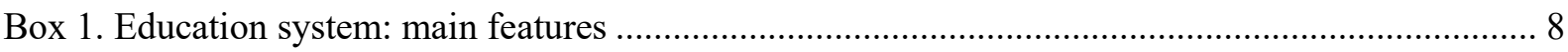

Box 2. Explaining PISA results for Iceland: an empirical analysis................................................... 15

Box 3. Improving the effectiveness of teacher-appraisal system: international evidence..................... 21

Box 4. Potential impact of reforms of out-of-work benefits on work incentives in Iceland ................. 40 


\title{
Fostering strong and relevant skills in Iceland
}

\author{
By Vassiliki Koutsogeorgopoulou and Laura Brogi ${ }^{1}$
}

Iceland enjoys high labour force participation and employment rates in international comparison, especially among women, and has a highly educated workforce (Figure 1). Although labour productivity growth has increased in recent years, the level of productivity remains below the average of Nordic countries, affected by skills mismatches and weakening school performance. Rapid technological change will add to pressures to train workers to cope with new challenges. In the future workers are likely to change occupations several times more in their lives than currently due to expected technological change. This underlines the need to provide the labour force with the skills needed for adapting to the expected changes.

There are two broad skills challenges that Iceland needs to address going forward. First, it is key to build a strong base by ensuring that young people leave compulsory education with the skills needed for further development and lifelong learning. This requires reducing the large share of students with low proficiency levels in literacy and numeracy, according to PISA findings (Figure 1), and also equipping young people with a broader set of skills including, for instance, creativity and collaborative skills that go beyond the competencies measured by PISA. Second, the skills and qualifications of Iceland's labour force should be better aligned with the demand for different skills in the country, which is also likely to change further with technological developments. Many occupations requiring high skills are facing shortages, while many workers are over-qualified for the jobs they do, implying that they are not meeting their productive potential. Using existing skills effectively is as crucial as developing them. Some of the skills shortages have been filled by immigrants, although they are not always well integrated in the labour market.

This paper takes stock of recent policy initiatives to address these challenges, indicating areas where further reforms are needed. The paper focuses in particular on education, lifelong learning (adult learning) policies, activation programmes, unemployment benefits and initiatives helping immigrant labour market integration. All these policy areas are key ingredients to a comprehensive approach for developing the appropriate skills and making the best use of them. Well-developed skills assessment and anticipation exercises are essential to inform policy decision.

\footnotetext{
${ }^{1}$ Vassiliki Koutsogeoropoulou is member of the OECD Economics Department. Laura Brogi was at the Economics Department at the time of writing and is now Junior Data Scientist at Fabricalab S.r.l. The authors would like to thank Hansjoerg Bloechliger, Isabell Koske, Alvaro Pereira, Piritta Sorsa, Douglas Sutherland (OECD Economics Department), Romina Boarini (General Secretariat), Olga Rastrigina, Daniele Pacifico, Alessia Forti (OECD Directorate for Employment, Labour and Social Affairs) and Icelandic officials for their valuable comments and feedback on earlier drafts. Special thanks are due to Guðmundur Porgrímsson (Department of Analytics, Directorate of Education, Iceland). for providing useful data for the empirical analysis in this paper. Special thanks also go to Anne Legendre for research assistance and Assa Fofana for editorial assistance (both from the OECD Economics Department).
} 
Figure 1. Iceland faces skills-related challenges

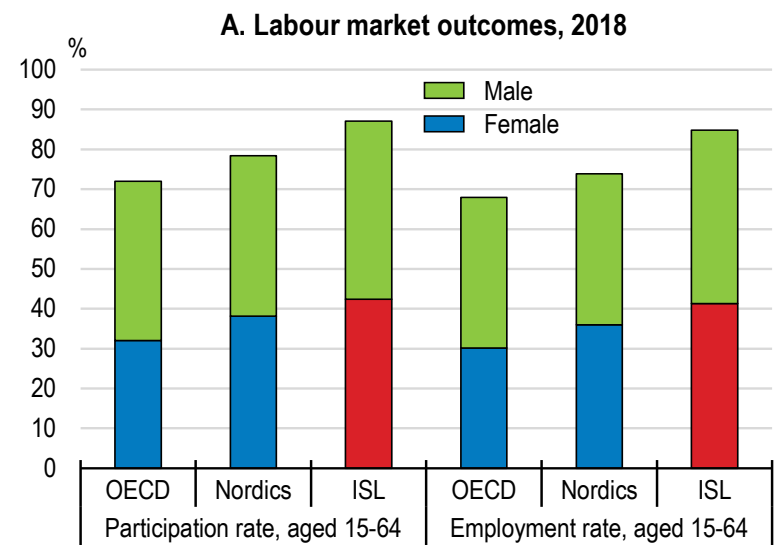

C. Labour productivity, 2018

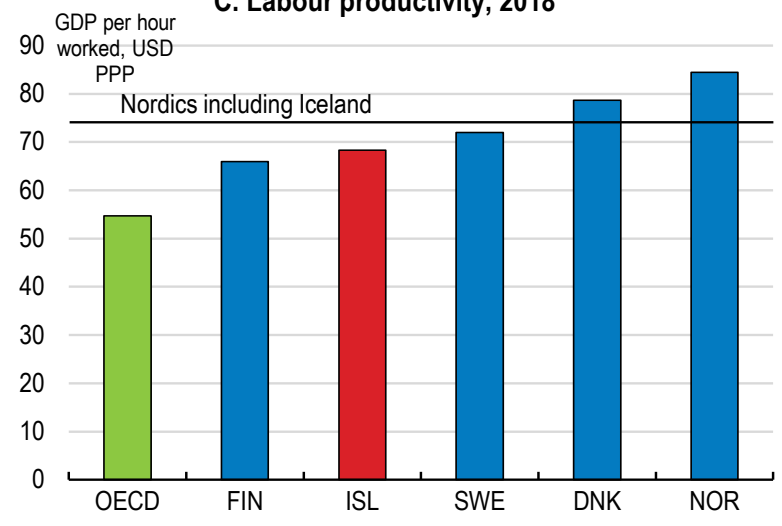

E. Employment growth and skills needs ${ }^{2}$

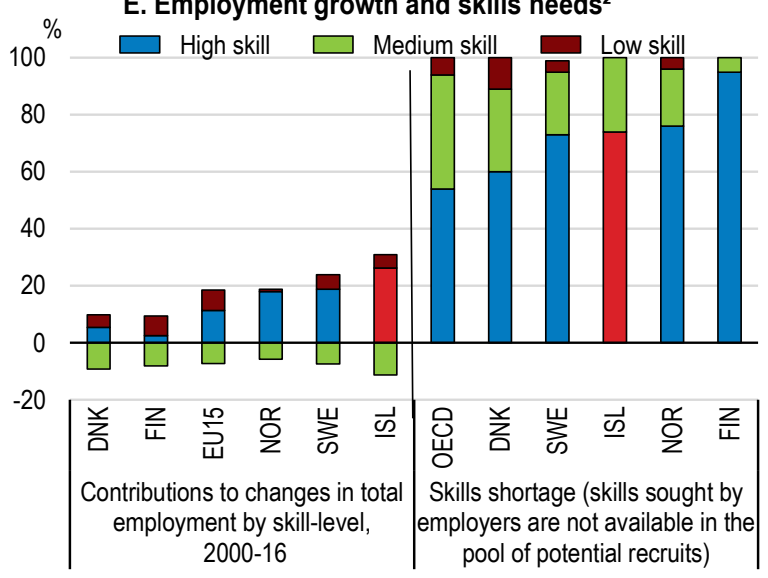

B. Labour productivity trend
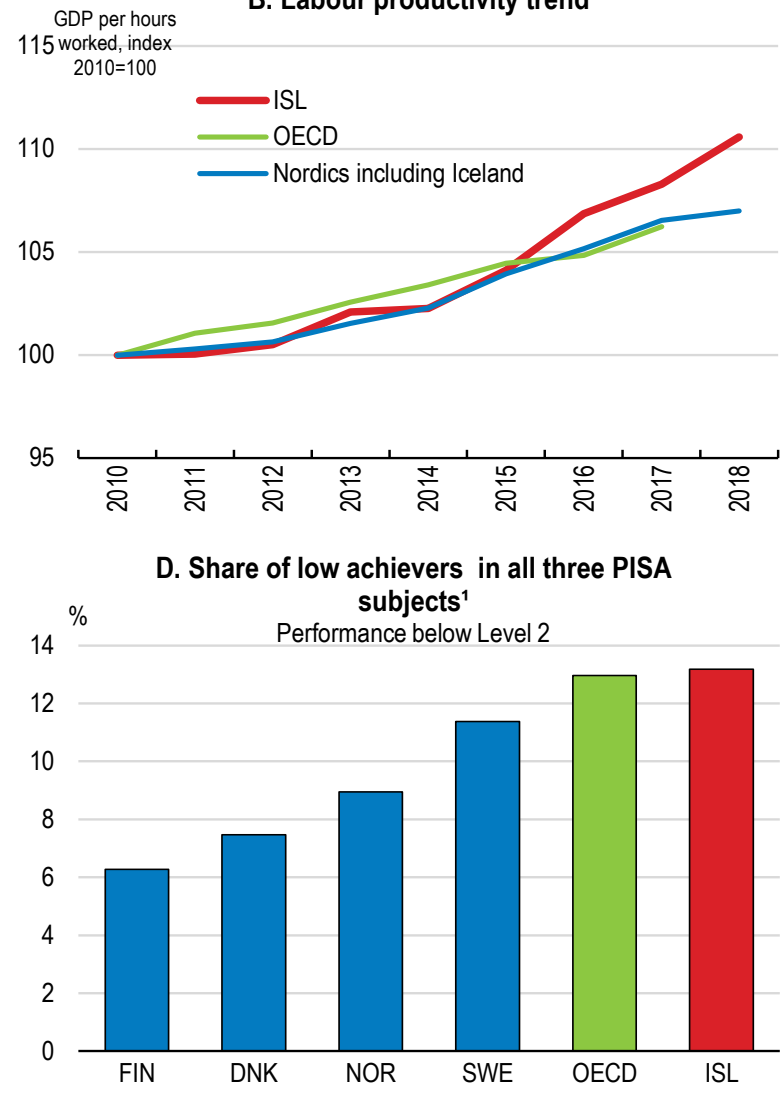

F. Qualification mismatch, $2016^{3}$

$\% \square$ Matched $\square$ Overqualified $\square$ Underqualified

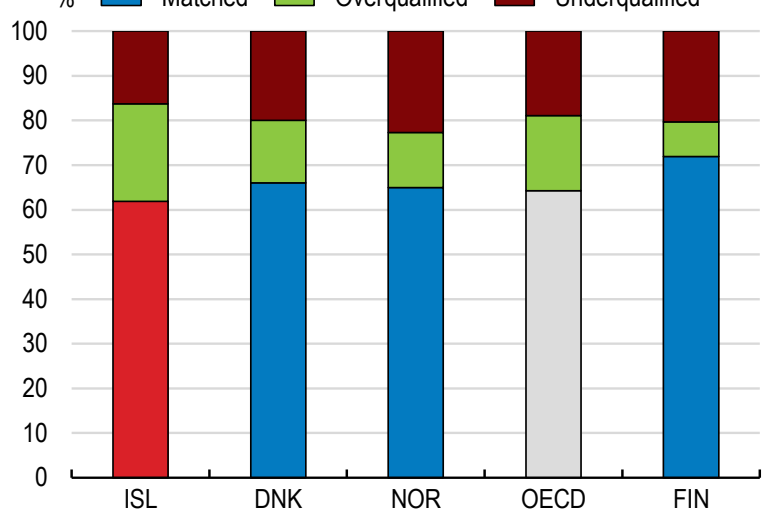

1. Data refer to 2015 PISA results for reading, maths and science. "Level 2" is considered the PISA baseline level of proficiency.

2. High-skilled workers refer to ISCO occupational groups 1-3, medium-skilled to group 4-8 and low-skilled to group 9. Data refers to latest year available.

3. Qualification mismatch describes a situation for which a worker has qualifications that exceed (overqualified) or does not meet (under-qualified) the ones generally required for the job.

Source: EO database; OECD Education at a Glance (EAG) 2018; PISA 2015; OECD Skills for Jobs. 


\section{Building solid core skills}

\section{Iceland spends significantly on education but outcomes have deteriorated}

Iceland spends 0.8 percent point of GDP more on education than the average OECD country. The difference mainly reflects high levels of expenditure on compulsory education (primary and lower secondary education), which is almost fully publicly funded (Figure 2). Per student spending in primary and lower secondary levels exceeded the OECD average by one-third in 2015 . The targeting of education funding at compulsory education reflects, to a large extent, the "inclusive school" policy, stipulating that all students, irrespective of their disabilities, should have access to normal schooling (OECD, 2016 $\left.6_{[1]}\right)($ Box 1).

Figure 2. Iceland spends comparatively more on compulsory education
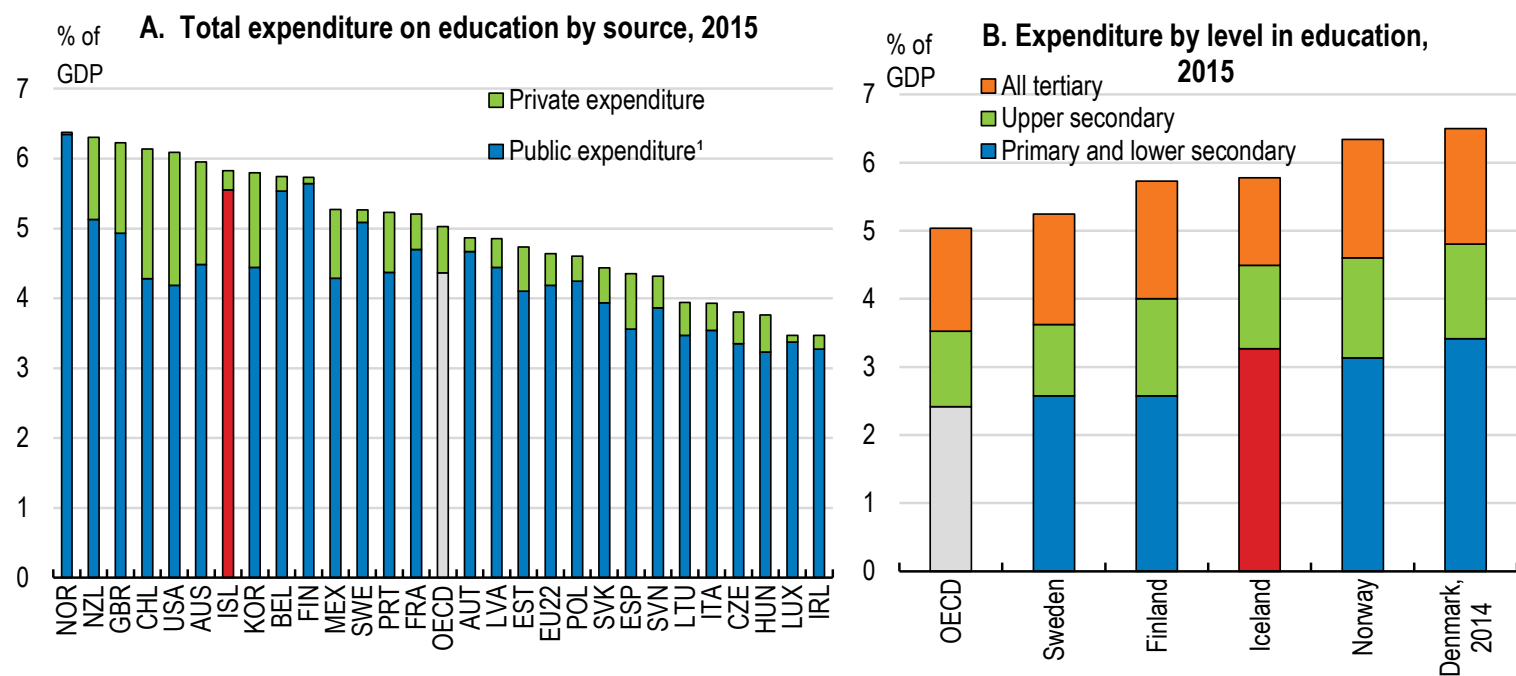

1. Included public to private transfers.

Source: Education at a Glance 2018.

StatLink त्ञाs https://doi.org/10.1787/888933996486

\section{Box 1. Education system: main features}

The education system in Iceland is divided into four levels: pre-school, compulsory, upper secondary and higher education (universities). The system is pre-dominantly publicly funded with very few private schools. The central government has the overall responsibility at all levels of education and sets the policies.

\section{Compulsory education}

The compulsory school, comprising primary and lower secondary education, is 10 years and caters to children between 6 and 15 years of age. Pre-primary and compulsory education are underpinned by the principle of inclusiveness, stipulating that all students independently of their disabilities should have access to normal schooling. There are currently 169 compulsory schools in Iceland, with a large variation in size. Small schools are concentrated mainly in the rural areas. 
A comprehensive reform in 1996 devolved the responsibility for compulsory education to the municipalities. Local authorities are currently responsible for opening and closing compulsory schools, approving the school curriculum, organising school leadership and for allocating physical and financial resources. Schools (at all levels) enjoy a fair amount of autonomy as recommended by the OECD in general. The Municipal Equalisation Fund distributes grants to local authorities with the aim to even out differences in the cost of running schools and ensuring that all municipalities meet minimum requirements for schools.

\section{Upper secondary education (general and vocational streams)}

Upper secondary education starts at 16 years of age. The general education is three years leading to a matriculation exam, which gives access to higher education. Vocational education and training (VET) lasts between one and five years, depending on the programme. There are two types of schools: class-based schools for general education, and credit-based schools for mixed general and vocational education. There is an additional level for specialised VET and journeyman qualifications, which is located at the upper secondary institutions.

There are currently over 80 VET programmes available to students. VET students do not have an automatic access to higher education, but they can complete an extra matriculation exam, alongside their vocational studies.

The upper secondary education is funded and managed by the central government. Some upper secondary (and higher education) institutes are government dependent private institutes. The funding system is in the process of being overhauled. Schools create their course descriptions and make proposals for programmes that have to be approved by the education authorities.

\section{Tertiary education}

The tertiary sector comprises 7 universities (4 public and 3 private) and caters to 18000 students in total. All tertiary institutions in Iceland have the status of universities. There are no specialised VET institutions at the tertiary level, but some are more oriented towards VET programmes than others. Examples include, the art academy and the agricultural university.

The main source of income for universities is public funds. Around $2 / 3$ of the allocation is for teaching and is based on a funding model that takes into account the number of students (FTE) (approximately 95\%) and, to a much lesser extent, the number of those who graduate (approximately 5\%). Both are calculated on the basis of price categories for different fields (15 categories for exams). One-third of the government funding allocated to each higher education institution is determined on a historical basis. No criteria exist for research. The funding system is currently under review.

Source: Ministry of Education, Science and Culture.

Despite high spending levels, educational outcomes are not satisfactory. Icelandic 15-year olds scored below OECD average in all three subject areas (science, mathematics, reading) of the 2015 PISA (Figure 3). Moreover, performance in PISA tests has declined over time. Around $13 \%$ of students approaching the end of compulsory education did not reach the PISA baseline level (Level 2) of proficiency in all three subjects of the assessment, close 
to the OECD average but higher than in other Nordic countries (Figure 1). The proportion of low performing students has increased from 2009 to 2015 in all core domains of PISA, while that of top performers (i.e. students achieving proficiency levels 5 or 6 ) has been sliding over time (Figure 3).

Figure 3. Low and declining PISA scores

A. PISA scores 2015

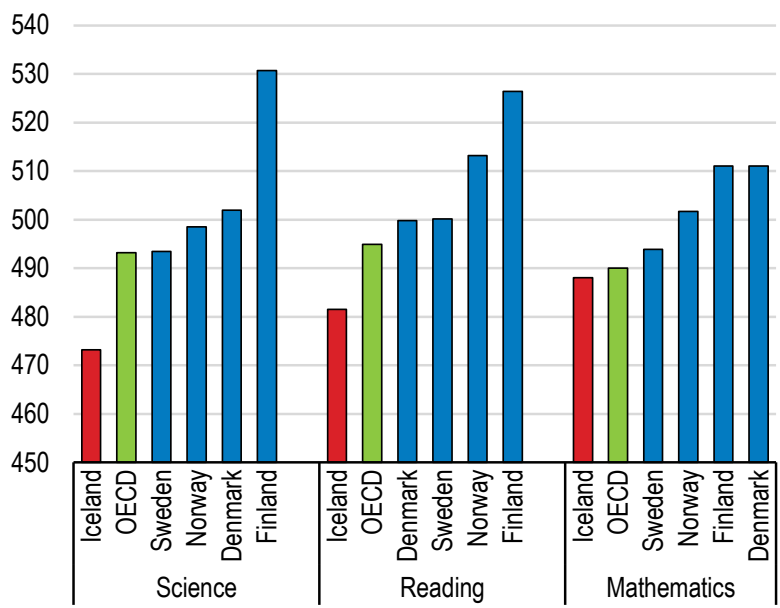

C. Share of low achievers in Iceland

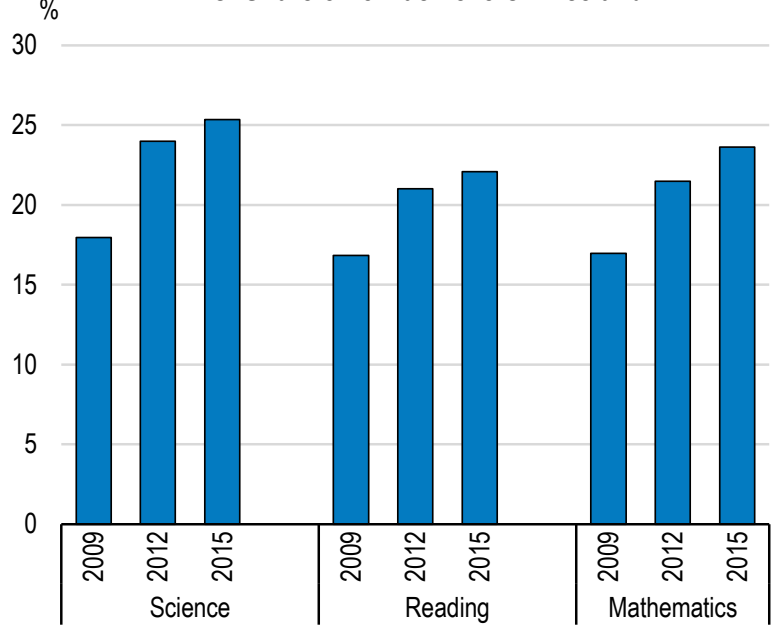

B. Trend of PISA scores in Iceland
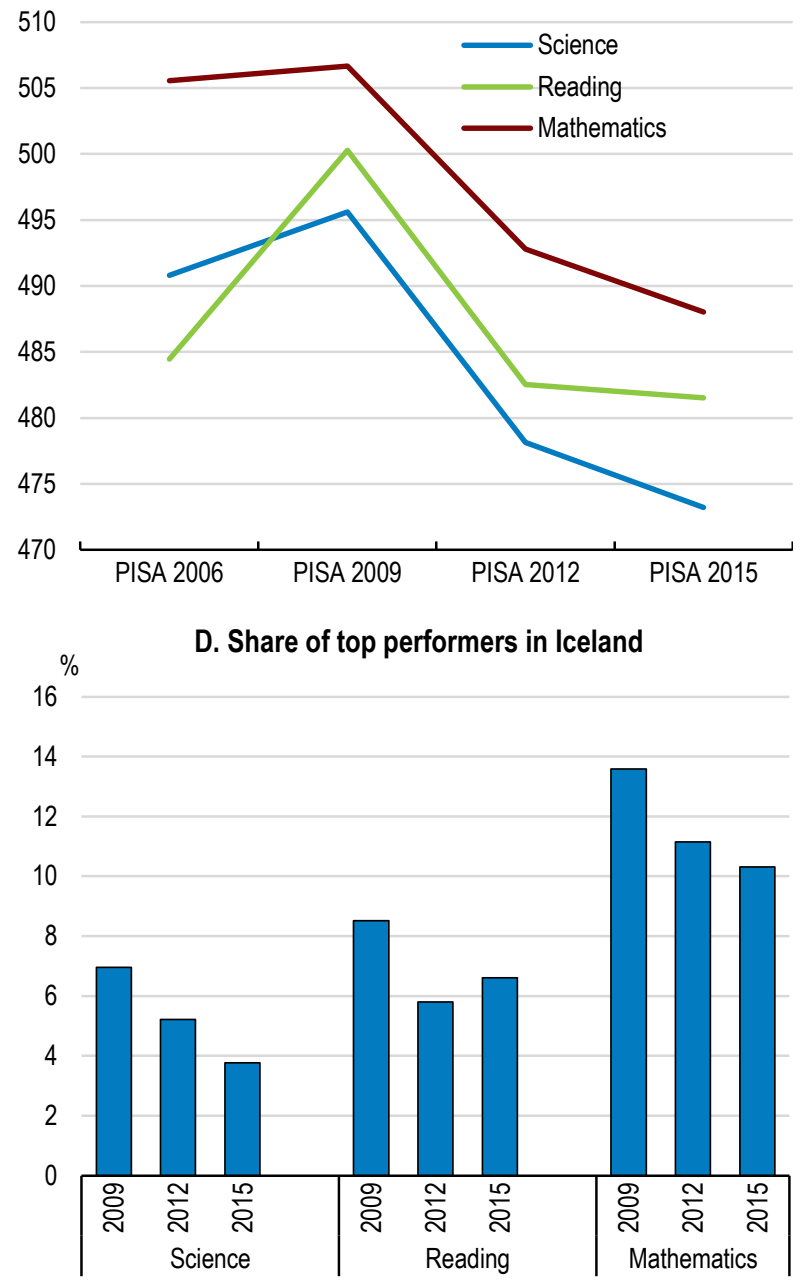

Note: "Low achievers" refers to students who perform at below 2 Level of PISA proficiency in each of the three subjects; and "top performers" to students who achieved Level 5 and above in each of the three subjects. Source: PISA 2015.

\section{StatLink त्गा5 https://doi.org/10.1787/888933996410}

Immigrants, which make up 7\% of 15 -year-old students, perform less well in the PISA tests than their native counterparts, even if Iceland's education system is very equitable (Figure 4 and Figure 5). The performance gap remains regardless of socio-economic background. In reading literacy, the PISA score difference is over 60 points, which is equivalent to more than one year of schooling, with first generation immigrants performing particularly poorly. Students from an immigrant background are also at least twice as likely as native students to fail achieving the baseline PISA level, especially in reading. This weak performance is 
further reflected in the low enrolments of immigrant students in upper secondary education compared to native students. OECD cross-country evidence suggests that students with poor PISA scores do not generally catch up later in life (OECD, 2015 $\left.5_{[2]}\right)$. This is also supported by the relatively smaller proportion of "resilient" students in the case of immigrants compared to their native counterparts, with the corresponding shares standing at $10 \%$ and $18 \%$, respectively (OECD, 2016 $[3]$ ). "Resilient" students are those who manage to perform better than predicted by their socio-economic status. This calls for measures to better integrate immigrants (see below).

Figure 4. Immigrant students underperform by a wide margin

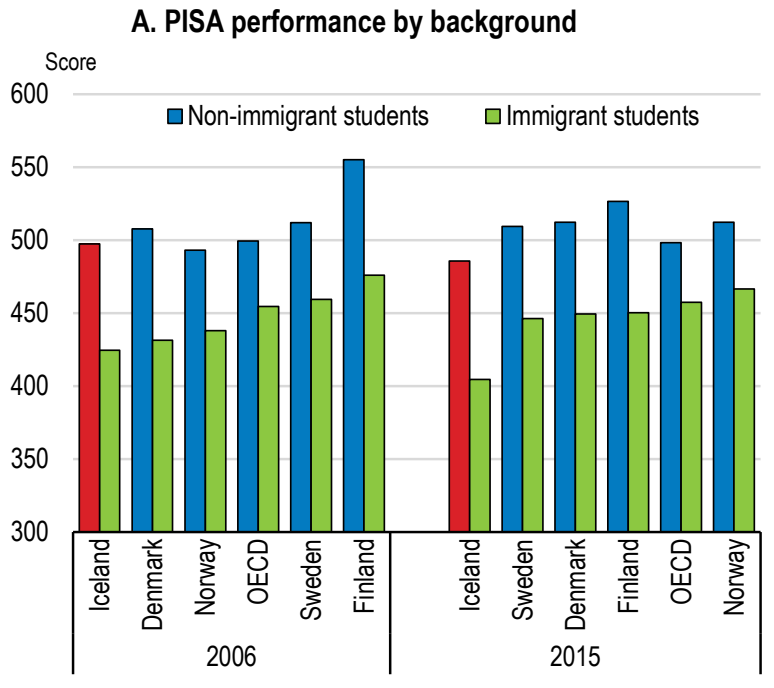

C. Percentage of low performers (below Level 2)

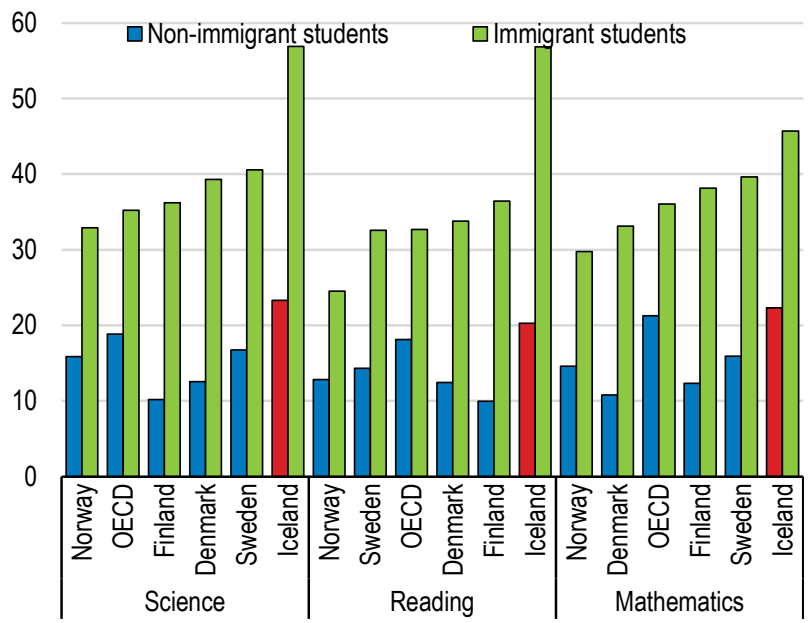

B. Differences in PISA performance between Score-point non-immigrant and immigrant students

difference $\square$ Before accounting for students' socio-economic status $120 \quad$ and language spoken at home $100 \square$ after accounting for students' socio-economic status

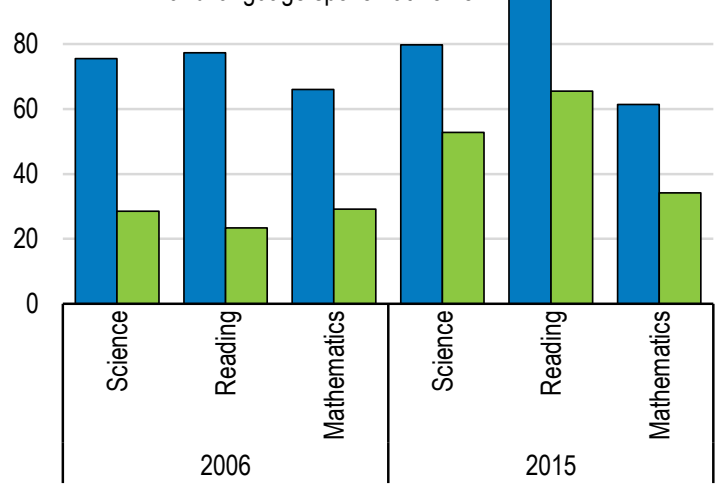

D. Enrolment rates in upper secondary education

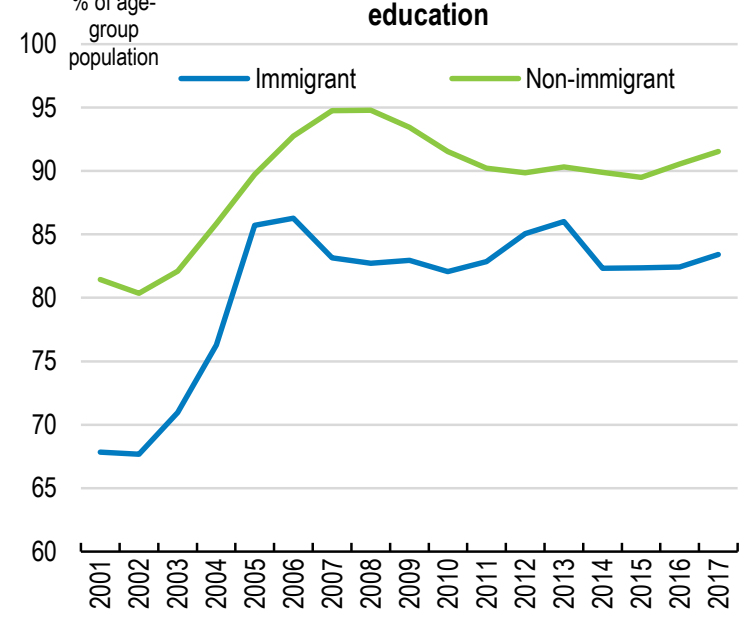

Source: PISA database. 
Figure 5. Socio-economic background has a small impact on students' outcomes

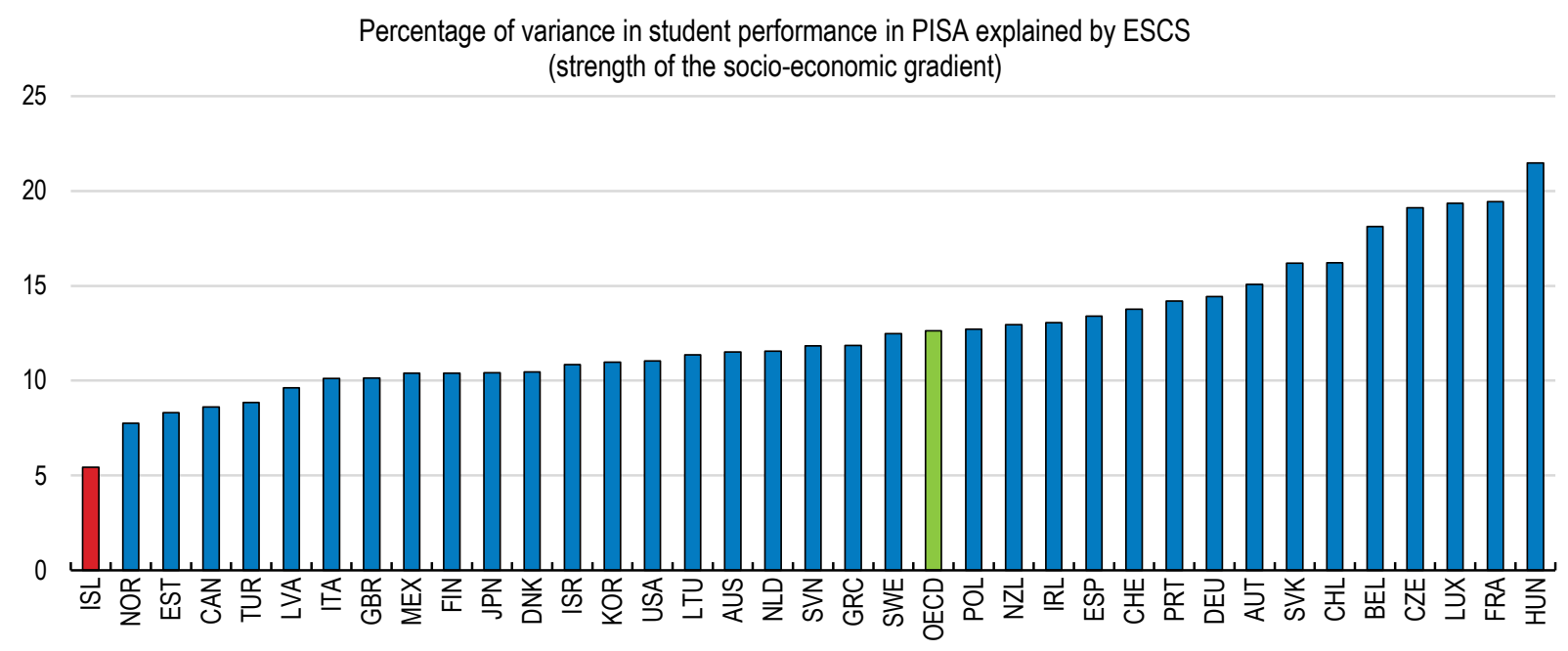

Source: PISA database.

StatLink 게대 https://doi.org/10.1787/888933996524

There are also growing regional inequalities in educational performance. When urban and rural students are compared, the former do better in science PISA scores by 17 points, while the difference disappears when the socio-economic profile of both students and schools are taken into account (Figure 6). The rural-urban gap in performance persists, however, as further analysis reveals, when controlling for additional school and student characteristics (Box 2). Rural students also underperform compared to their urban peers in terms of upper secondary graduation rates, as well as expectations for pursuing university studies (with the gap persisting after taking students socio-economic status into account). Both are very important to further skills development. A recent study, focusing on Iceland, highlights the lower levels of ambition among students in rural areas (Nissinen et al., 2018 ${ }_{[4]}$ ). 
Figure 6. Rural-urban differences in education performance
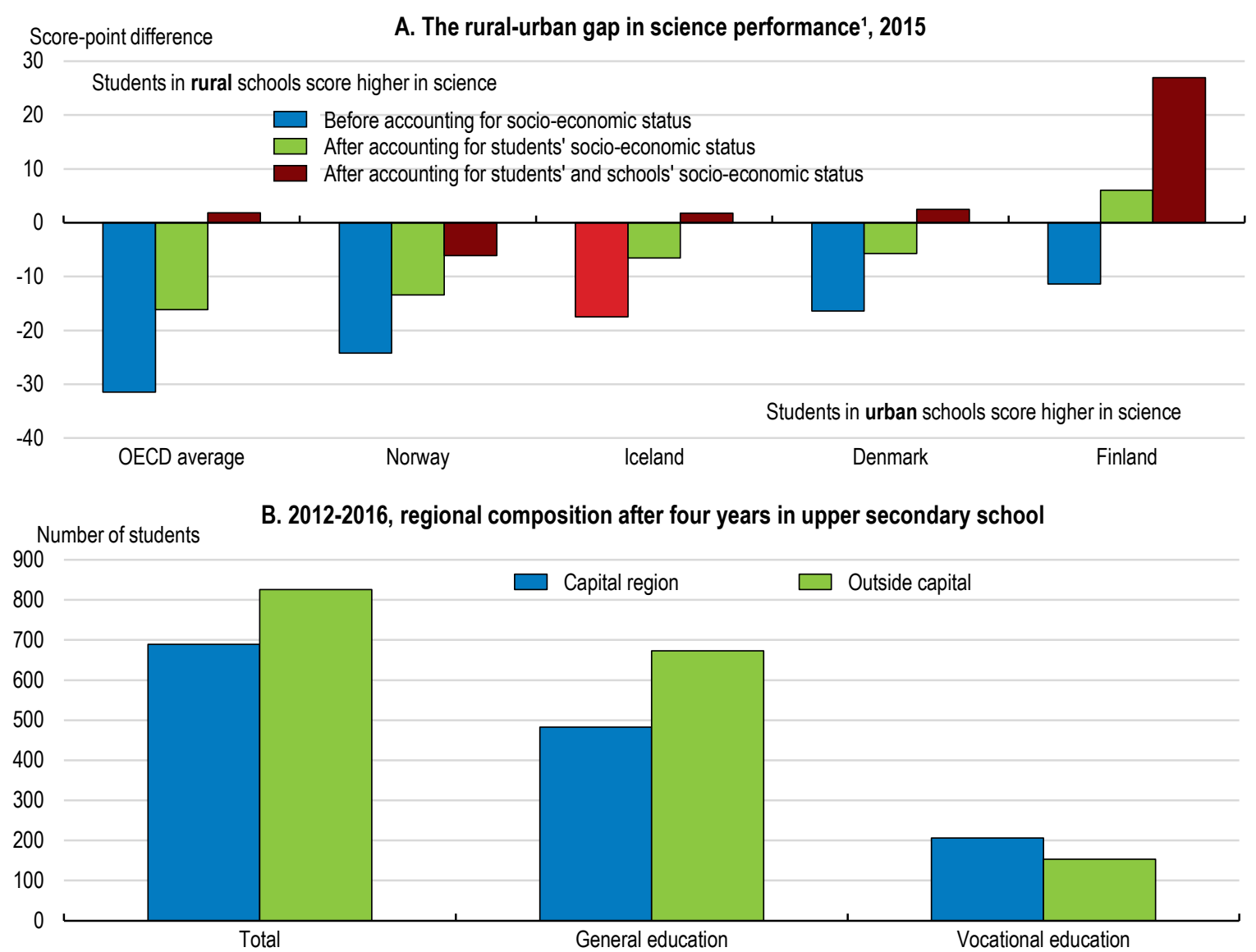

$1.2 \frac{\text { Odds ratio }}{\text { C. The rural-urban gap in educationats in rural schools more likely to expect completing a university degree }}$

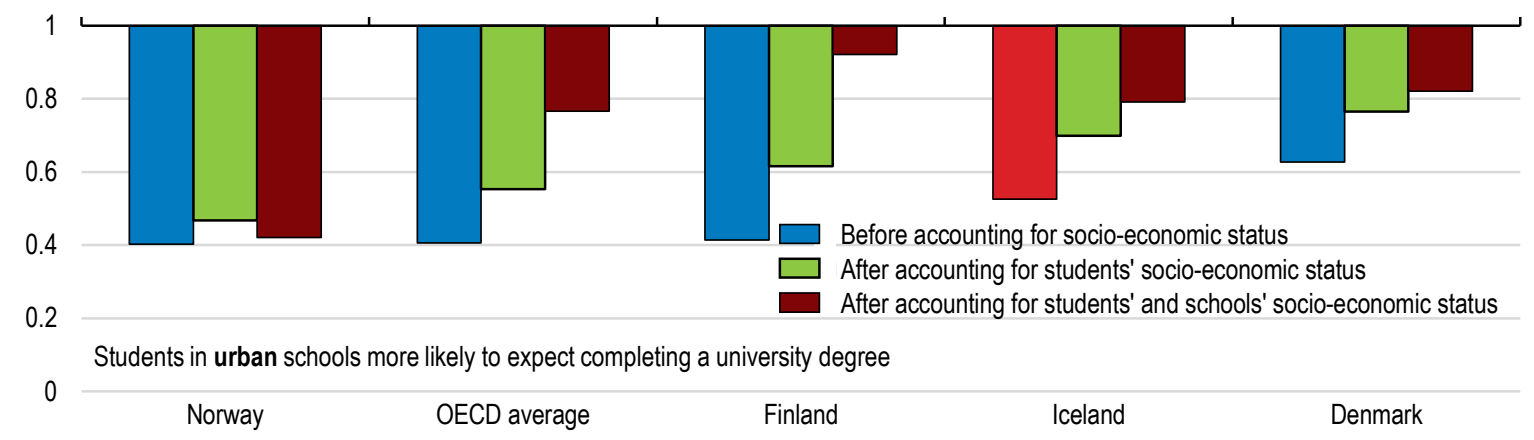

1. In PISA, schools located in towns of 3000 inhabitants or less are defined as rural while urban ones refer to cities with 100000 inhabitants or more.

2. The odds ratio is a measure of the relative likelihood of a particular outcome across two groups; an odds ratio below one denotes a negative association; and an odds ratio of one implies no association.

Source: Echazarra, A. and T. Radinger (2019), "Learning in rural schools: Insights from PISA, TALIS and the Literature ", OECD Education Working Papers, No. 196, OECD Publishing, Paris; Statistics Iceland.

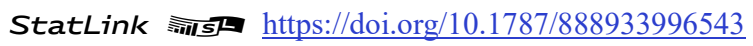

The gender gap in reading skills is also large. Around $24 \%$ of 15 -year-old boys, compared to $10 \%$ of girls, failed to achieve the baseline level of efficiency, according to PISA 
findings, with the difference exceeding the OECD average and the levels in peer countries

(Figure 7). The difference is even larger for rural boys (Statistics Iceland, 2018 $\left.{ }_{[5]}\right)$.

Figure 7. A large gender gap in reading literacy remains

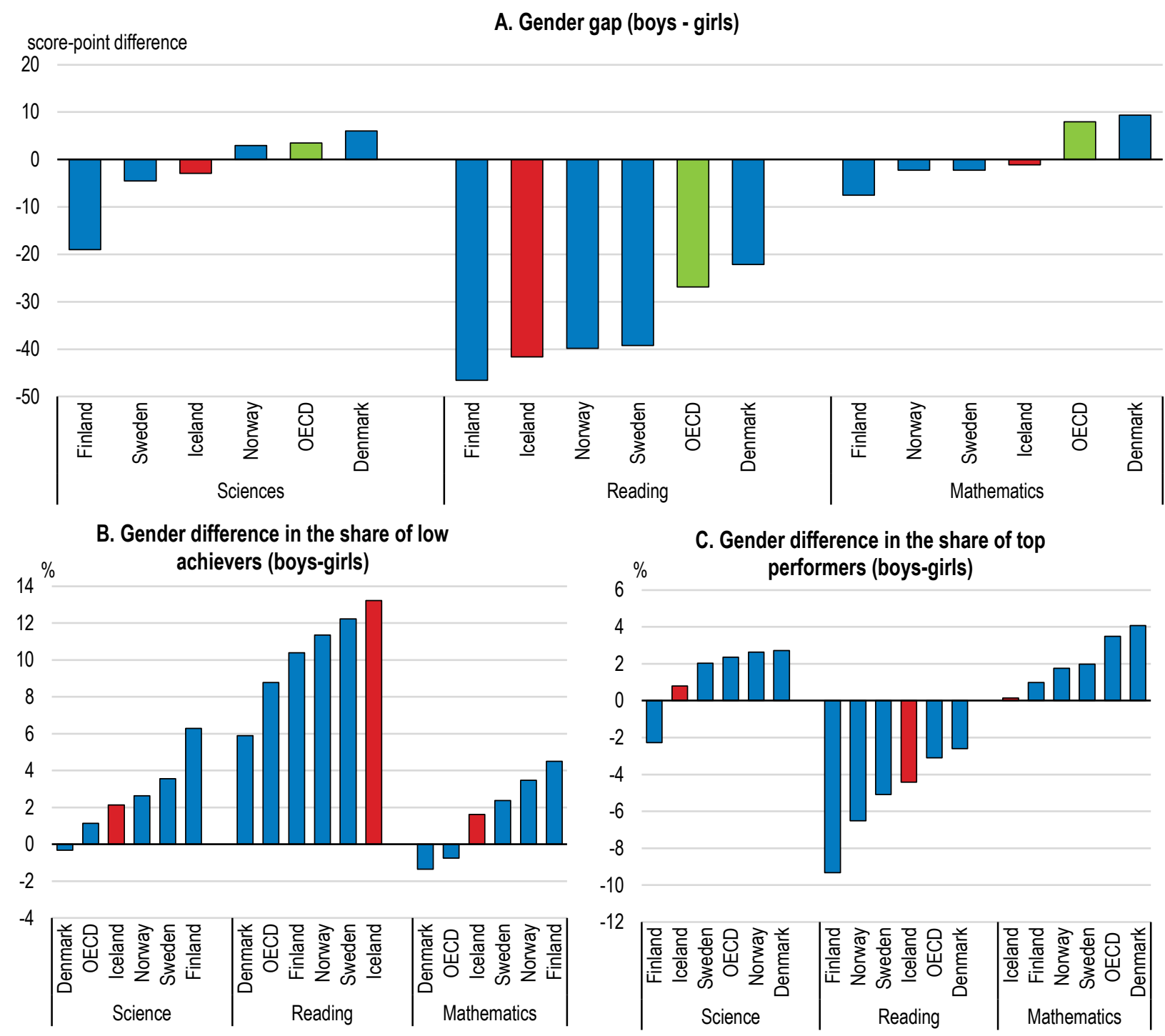

Note: "Low achievers" refers to students who perform at below 2 Level of PISA proficiency in each of the three subjects; and "top performers" to students who achieved Level 5 and above in each of the three subjects. Source: PISA 2015.

StatLink 세메 https://doi.org/10.1787/888933996562

Several, complex - and to an extent, inter-related - factors affect learning outcomes, ranging from students' characteristics and interests to the quality of the education system per se. This multi-dimensionality is also highlighted by the results of an empirical analysis of PISA data for Iceland, carried out in the context of this Survey (Box 2). Socio-economic background, immigrant status and gender were all found to affect student performance, as are certain school characteristics, including location, teacher shortages and teachers' academic qualifications. Of course, teacher quality goes beyond academic credentials as 
skills and competences are also shaped by other factors, notably the pre-service practical training that new teachers receive and in-service professional development. Recent OECD analysis further highlights the importance of behavioural differences in explaining performance gaps in different academic subjects, especially between girls and boys, and the need, in this context, to encourage student attitudes through collective efforts (OECD, $2015_{[6]}$; OECD, 2016 $\left.6_{[3]}\right)$. Overall, a comprehensive reform approach is required to improve student outcomes that entails specific measures focusing on areas of particular concern such as weak reading skills, and more broad measures that strengthen the foundations of the education system, with teaching quality at the core. These are discussed below.

\section{Box 2. Explaining PISA results for Iceland: an empirical analysis}

OECD analysis uses data from the six waves of PISA database for the period 2000-2015 to identify the main drivers of student performance in Iceland. A student-level education production function is estimated for each wave, with PISA test scores as dependent variable and students' and schools' characteristics as independent ones. Each PISA subject area (reading, mathematics, science) is analysed separately using an ordinary least squares (OLS) regression. In addition to a cross-sectional analysis, pooled cross-sectional and panel analysis, with fixed and random effects, were also employed for a sub-sample of schools to shed additional light to the evolution of PISA outcomes over time (Brogi and Koutsogeorgopoulou, forthcoming $\left[{ }_{[7]}\right)$

The cross-sectional analysis of the last wave (2015) shows that student characteristics play an important role in explaining PISA scores, and this is true for all six waves of the assessment (Figure 8). More specifically, student's social background has a significant positive effect on test scores, which remains stable overtime for all three subjects. On the other hand, immigrant status has a significant negative impact on scores, especially in the last wave. Gender appears to have a strong influence only in the case of reading, with girls performing significantly better than boys.

Regarding school characteristics, rural schools outperformed their urban counterparts until mid-2000s. The performance gap was reduced substantially in the following years, however, and was even reversed in 2015 with urban schools performing better in science, and especially, in maths (Figure 8). These results hold when taking into account several school and student characteristics that go beyond socio economic status (ESCS) and consider the whole PISA sample.

School-level variables also play a role. For instance, teachers' shortages have an adverse impact on student performance, which is statistically significant in almost all waves, while teachers' academic qualifications (in terms of holding a university degree) do not always matter. The quality of school material (e.g. laboratories) turns out to be another important variable, at least in some waves. Overall, the findings highlight that several interactive factors can help explain Iceland's PISA performance. 


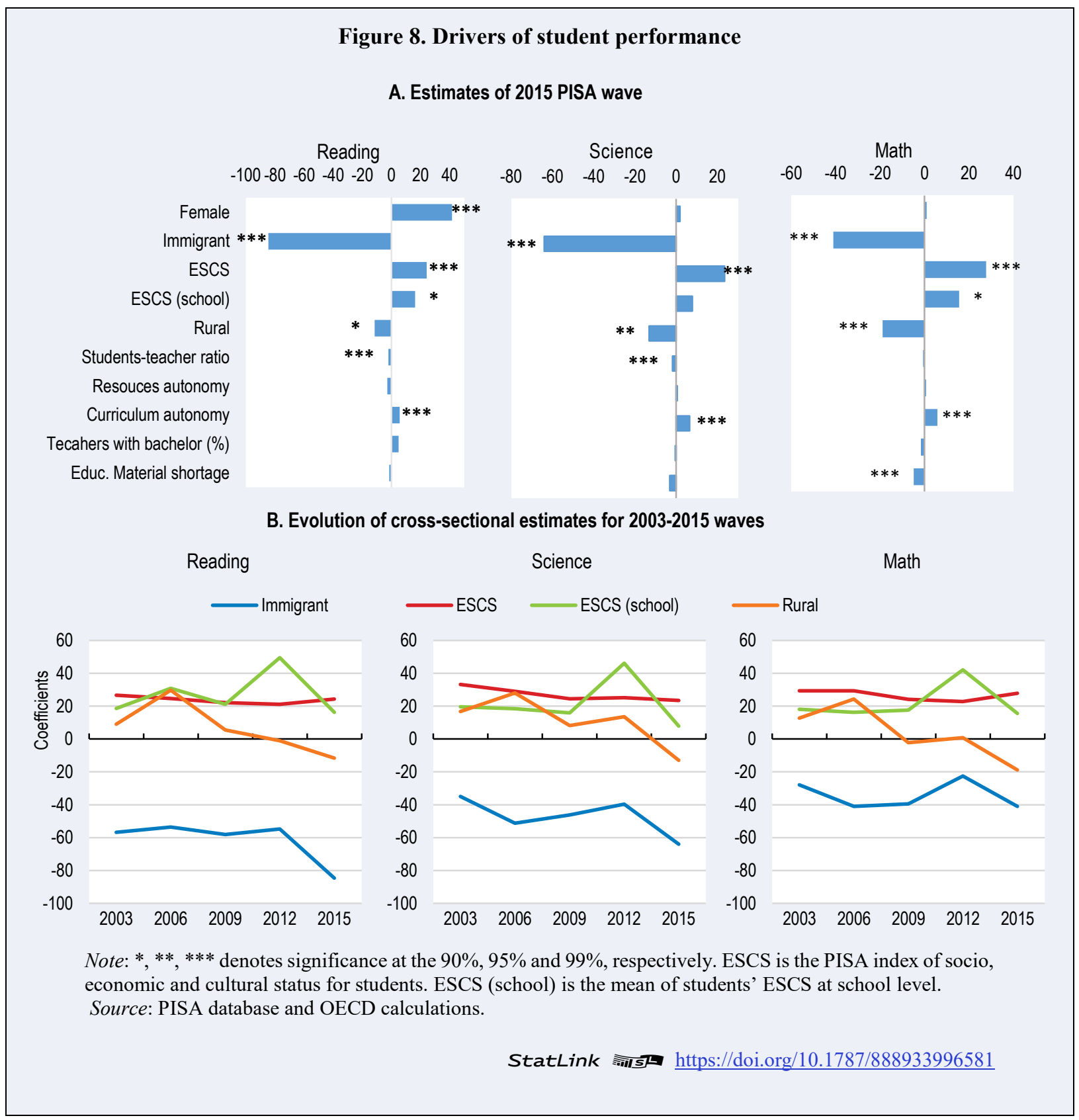

\section{Meeting the reading skills target}

A 5-year national literacy strategy was launched in 2015 in the wake of a government White Paper on education reform in the previous year. The target was that at least $90 \%$ of students in compulsory school meet minimum reading standards (Level 2) by 2018, up from $79 \%$. Efforts to achieve the target involved the development of reading proficiency standards for each level of compulsory education, as well as of new assessment tools (fluency tests) for the regular measurement of reading skills (Sigpórsson, 2017 $[8]$ ). Moreover, the literacy initiative has allocated funding for a period of 5 years for counselling and support to municipalities and schools and awareness raising (Kavli, 2018[9]). A Directorate of 
Education was created in 2015 to monitor the implementation of the national initiative on literacy and a task force was set up to this end.

These measures go in the right direction towards improving reading literacy skills. Regular reading fluency assessments provide useful information on students' achievement at different school stages, enhancing the capacity for diagnosing reading difficulties. A number of local authorities and schools have already adopted reading policies with specific objectives and took actions to improve reading skills (Directorate of Education, 2017 ${ }_{[10]}$ ). Efforts need to continue, however, as the reading literacy target set by the 2014 White Paper has not yet been achieved. A swift implementation of the measures under the literacy initiative is important. Strengthening literacy as a separate subject in school curricula for higher grades (5th and above) could also be considered, given evidence that literacy skills deteriorate as students move to higher grades.

Immigrant students require particular attention in view of their relatively poor reading skills (Figure 4) and the growing share of students with Icelandic as a second language. The corresponding share of such students in compulsory education stood at $10 \%$ in 2017 , compared to only $1 \%$ two decades earlier. Offering language training, in addition to regular course work, is important. Recent OECD research highlights that integrating immigrant children into mainstream classes is associated with better outcomes (OECD, 2015 [11]). This should be accompanied by appropriate training of teachers who work with immigrant students.

The authorities have launched a number of initiatives to promote the use of Icelandic language, which they find important given the small number of native speakers. Recent research into the development of the language has highlighted how vulnerable this is in an age of disruptive advances in digital technology (Rögnvaldsson et al., 2018 ${ }_{[12]}$ ). Appropriately, immigrant children are given special attention to acquire adequate language skills. To this end, the Municipal Equalisation Fund provides grants to schools to support immigrant children, which benefits rural schools in particular. Moreover, a working group was set up by the government to analyse the situation of immigrant students in Iceland, which is expected to deliver proposals before the end of 2019.

Overall, ensuring that the majority of students in compulsory education reach the minimum reading standards is a key challenge. Setting clear goals for top performers in reading literacy, and perhaps other competency areas of PISA, and developing the necessary tools to achieve such goals, is also advisable. Reforms to enhance teaching quality, discussed below, play a key role in this regard.

\section{Improving teaching quality}

The teaching profession does not appear to be attractive to young people in Iceland, as indicated by the falling share of those under 30 years entering the vocation (Figure 9). This raises concerns not only about future teacher shortages, but also about quality. The proportion of un-licensed teachers in compulsory education has increased in recent years, reaching around 12\% in 2018 (Figure 9). This may reflect the high employment turnover of fully qualified teachers, with many teachers leaving the profession especially after the first years of their career. Under current arrangements, a less qualified applicant ("out-oflicence" teaching) can be hired when no fully qualified teacher is available. The "qualitative" shortfalls are particularly large in areas outside the capital, such as Westfjords where the rate of teachers without a licence has reached $28 \%$. In addition, licenced teachers are getting older, with an average age close to 48 years in 2018, compared to 36 years of teachers without a licence. 
Figure 9. The teaching profession faces challenges at primary and lower secondary level
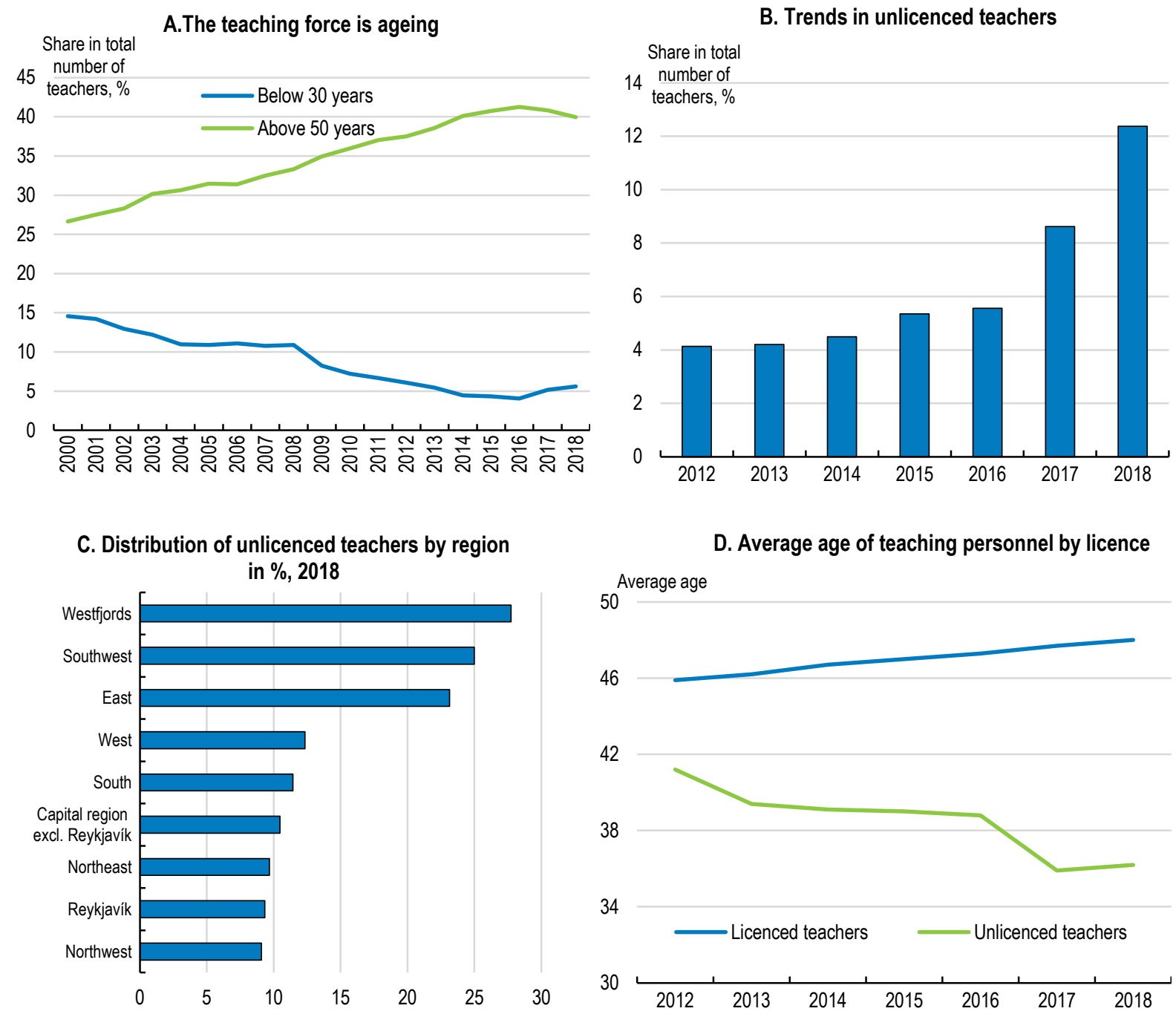

Source: Iceland statistics and OECD calculations.

\section{StatLink त्ताज् https://doi.org/10.1787/888933996600}

Relatively low salaries compared to other professionals and a slow wage progression can reduce the attractiveness of the teaching profession (Figure 10) (Chapter 2 of the 2019 OECD Economic Survey of Iceland). After 15 years of service the salary of a lower secondary teacher in Iceland is only 10\% higher than the level of the starting salary, with the difference increasing to $15 \%$ when comparing the final and starting wage. The corresponding figures for the OECD average stand at $41 \%$ and $78 \%$ respectively. OECD research concludes that relative earnings in teaching and non-teaching occupations, and their likely growth over time, have a strong influence over a graduate's decision to become a teacher $\left(\mathrm{OECD}, 2005_{[13]}\right.$; OECD, 2014 $\left.{ }_{[14]}\right)$. 
Figure 10. Teacher salaries are relatively low
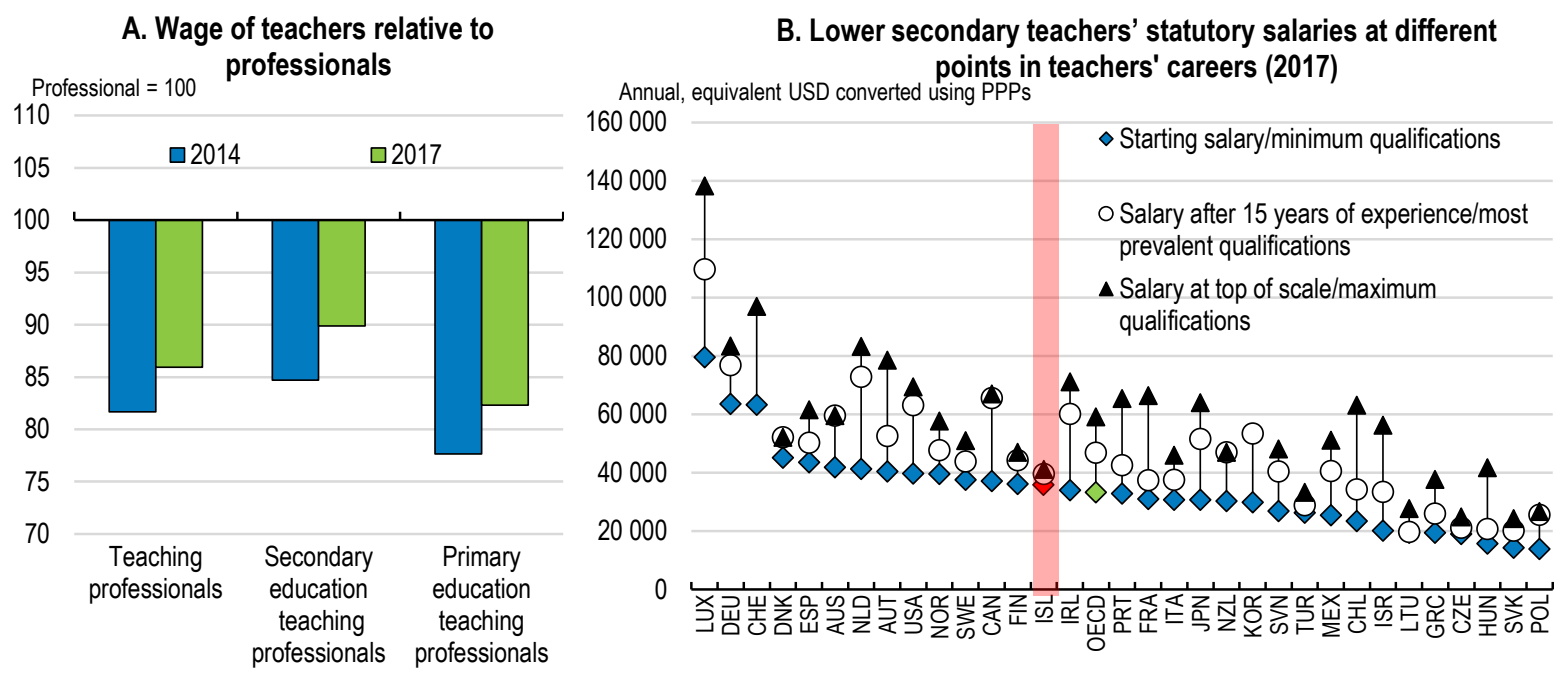

Source: Statistics Iceland; OECD Education at a Glance 2018.

StatLink ज्ञाजम https://doi.org/10.1787/888933996619

Some other aspects of the teaching profession may also affect its attractiveness as a career choice for young people. Icelandic teachers, for instance, spend comparatively more time on administrative tasks and classroom management, on the basis of the findings of the 2013 OECD Teaching and Learning International Survey (TALIS), at the expense of teaching time $\left(\right.$ OECD, 2014 $\left.{ }_{[15]}\right)$. Moreover and like in the other Nordic countries, a formal system of teachers' promotion that could make the process more structured and transparent is currently absent. OECD analysis concludes on the basis of behavioural evidence that, in addition to pay, extrinsic factors such as working conditions and career prospects, are important influences on whether people choose to become teachers or not (OECD, $\left.2005_{[13]}\right)$. The TALIS results for Iceland further show that many teachers feel that their work is undervalued.

Improving the image of the teaching profession and its competitive position in the job market through, for instance, public campaigns and well-designed financial incentives, could help attract new entrants to the field (OECD, $\left.2005_{[13]}\right)$. Transforming the teaching profession, however, requires a more comprehensive approach through well-coordinated strategies that strengthen quality. The ageing of the teaching workforce provides an opportunity for such reforms. Based on the experience of best performing countries, ensuring high teaching quality hinges upon an effective pre-service training, the presence of a wide-range of custom-made opportunities for in-service professional development, and coherent teacher-appraisal mechanisms (OECD, 2018 [16]).

Iceland faces important challenges in these areas with recent reform initiatives going in the right direction. In particular:

- Initial teacher education (ITE) programmes need to prepare novice teachers better for the realities of the classroom (Figure 11, Panel A). A 5-year master's degree is required since 2012 to enter the teaching profession at all levels. Class-based practice, however, also needs to be strengthened to help new teachers bridge theory and practice. Recent reforms that make the fifth year of the ITE programmes a paid part-time apprenticeship position at schools are a welcome step forward as they 
boost practical training, while also reinforce the links between schools and teacher education institutions. Extending the period of practical training could be another reform option. Some countries, for instance Ireland and Sweden, have also established minimal credit hours for pre-service class-based practice of teachers (European Commission, $2015_{[17]}$ ). ITE programmes that prepare new teachers for the diverse background of their students, through classes geared towards this end, are also important $\left(\mathrm{OECD}\right.$, forthcoming $\left.{ }_{[18]}\right)$.

- The participation of new teachers in induction programmes is relatively low. Around $60 \%$ of new teachers in Iceland work in schools providing formal induction programmes, not far from the OECD average, but only $20 \%$ of them report to have taken part in such programmes (Figure 11, Panel B). A similar pattern applies to mentoring programmes. Participation in induction/mentoring programmes is important for the smooth transition from initial teacher education (ITE) to the real school environment, while it can also reduce attrition among new teachers (European Commission, 2015 $5_{[17]}$ ). At the same time, schools need to be encouraged to offer well-designed, and carefully targeted, programmes (OECD, 2014 $\left.{ }_{[15]}\right)$. The main challenge in the case of mentoring schemes is to attract experienced teachers and train them to become effective mentors (OECD, 2019[19]). ITE and induction initiatives need to be closely aligned.

- There is scope to match better professional development opportunities to teachers' needs. Participation in professional development activities is high in Iceland, according to 2013 TALIS findings, but many lower secondary teachers report unmet needs in important areas such as developing ICT skills for teaching (Figure 11, Panel C). Providing a variety of bespoke opportunities for in-service professional development is crucial, and in line with best practice (OECD, 2018 $\left.{ }_{[16]}\right)$. The 2013 TALIS results also point to some other barriers to participation in professional development activities, such as conflicts between the training and work timetable, with scope for further improvement (Figure 1.11, Panel E). An expert panel, established by the government, is examining options for reform in the context of the Education Policy 2030 review.

- An effective evaluation system for teachers is absent. Iceland has no legislated teacher-appraisal policy as some other countries do, such as Australia and Canada, for example. In addition, a relatively low proportion of teachers in schools with formal appraisal practices have reported in the TALIS survey to have their classrooms directly observed as a means of assessment (Figure 11, Panel D). Classroom observations and teacher interviews are used extensively by high performing countries to evaluate teaching quality (OECD, 2018 $\left.8_{[16]}\right)$. More importantly, the TALIS results for Iceland suggest that the appraisal process has only a weak impact on teachers' skills development and their practices, highlighting the need for stronger evaluation and feedback. An OECD in-depth review of teacher appraisal systems provides a number of policy options for improving evaluation frameworks (Box 3) (OECD, 2013 $\left.{ }_{[20]}\right)$. The review concludes that it is the design and quality of teacher-appraisal mechanisms, rather than the existence of a formal appraisal, which make the process effective.

As a welcome step towards improving teaching quality, a new teacher competency framework was developed that will form the basis for teacher education and certification, hiring and promotion processes, professional development and training, and teacher 
appraisal. The new framework is expected by the authorities to provide a clear guidance to school leaders to focus on teachers' training and make it more performance oriented.

Recent initiatives also aim to increase the attractiveness of the teaching profession to young people through the launching of a campaign to enhance the image of the profession at pre-primary and compulsory schools and changes in initial teacher education. The latter include the provision of grants to students during their fifth year of study in order to reduce the need for student loans at the last year, in addition to making the fifth year a part-time paid apprenticeship (see above). Moreover, a law in 2019 introduces a common teacher certificate for all three school levels (pre-primary, compulsory, and upper secondary education), instead of three different ones as is currently the case, which could facilitate teacher mobility between schools and across school education levels.

Box 3. Improving the effectiveness of teacher-appraisal system: international evidence

- Establishing teaching standards to guide teacher appraisal and professional development.

- Resolving tensions between the developmental and accountability functions of teacher appraisal.

- Conducting regular developmental appraisals at the school level, based on frequent classroom observations and other sources of information.

- Ensuring that teacher appraisal feeds into professional and school development.

- Establishing periodic career-progression appraisal involving external evaluators.

- Preparing teachers for appraisal processes and strengthening the capacity of school leaders for teacher appraisal.

- Establishing links between teacher appraisal and career-advancement decisions.

Source: (OECD, 2013 $\left.{ }_{[20]}\right)$.

\section{Helping students to succeed}

Improvements in teacher quality play undoubtedly an important role in achieving better educational outcomes, but strengthening students' willingness to succeed is also essential. Icelandic students generally feel happy at school, which is an advantage of the education system. Stronger student assessment mechanisms, however, may be necessary to help improve school outcomes. Clearly defining the knowledge and skills students are expected to have attained at different stages of their education through standardised benchmarks to assess performance is important in this regard (OECD, 2009 [21]). Developing large-scale tests can be one way to assess student performance and also provide incentives to students to put greater effort into learning. But standardised tests have also drawbacks, including narrowing education goals to passing needs, that should be considered carefully (OECD, $2016_{[22]}$ ). Another possible (or complementary) approach is developing teaching capacity in assessing against standards or providing clear guidelines in marking assessments, and/or though effective peer-reviews (OECD, 2009 $\left.9_{[21]}\right)$. 
Figure 11. There is scope to improve teachers' training and professional development

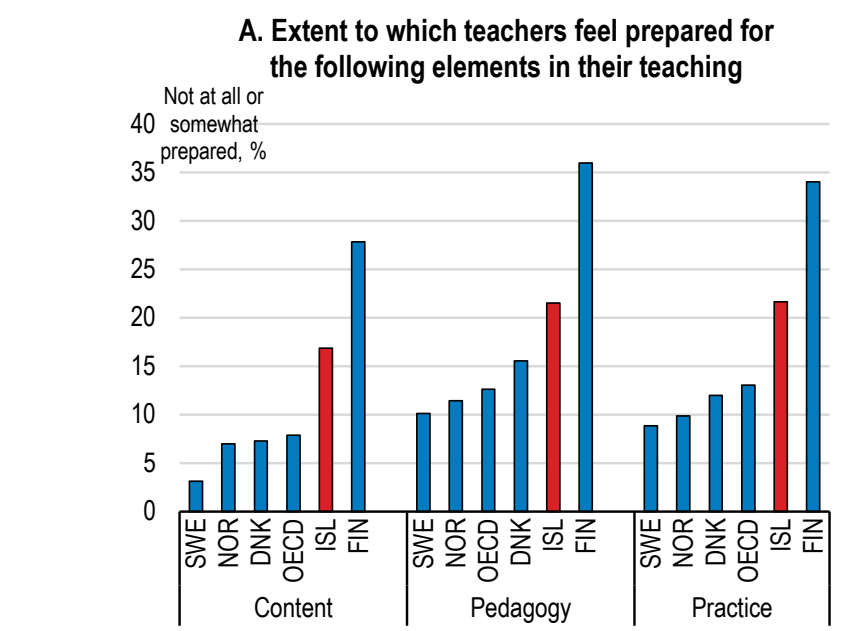

C. Teachers' needs for professional development
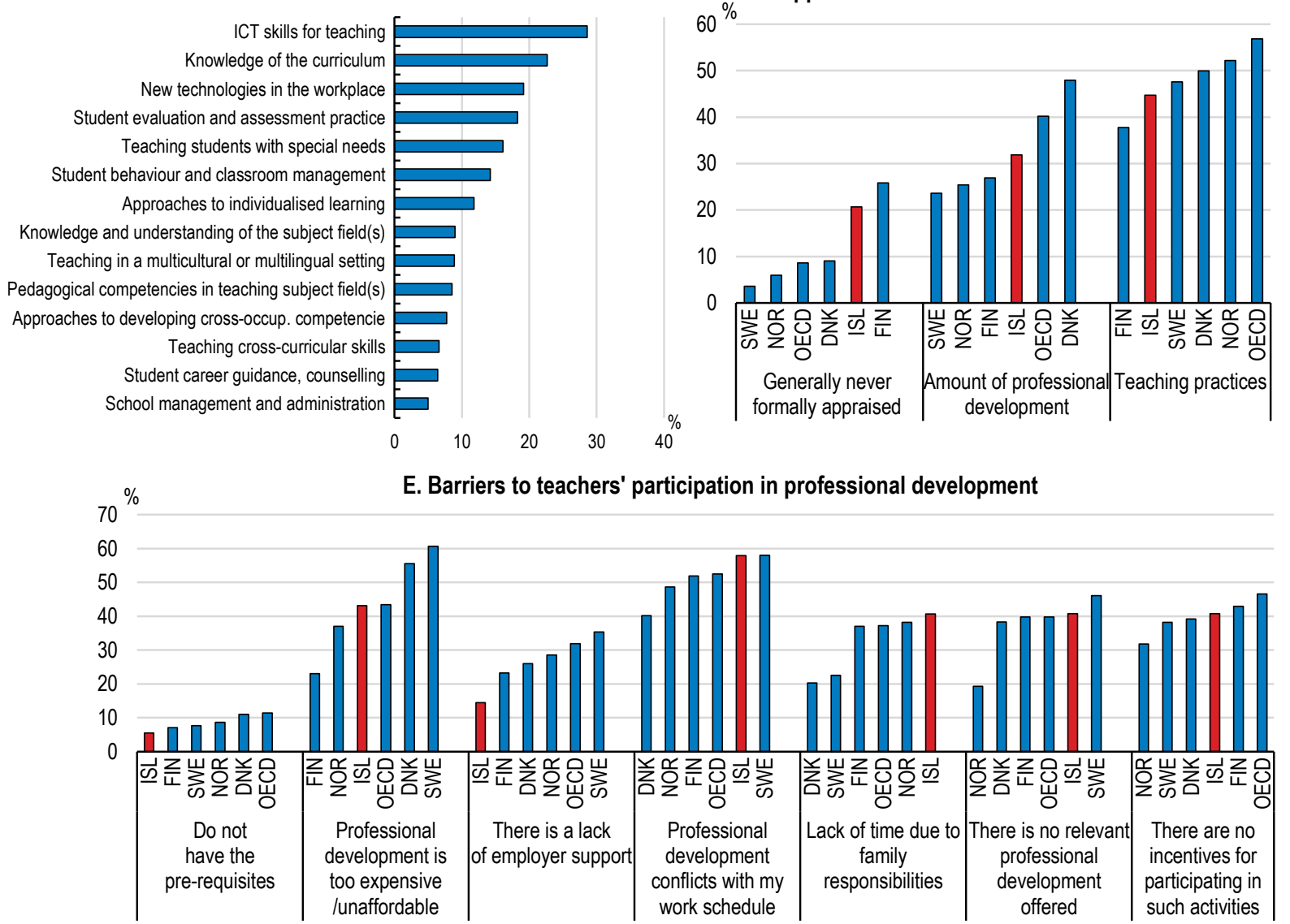

Note: Percentage of lower secondary education teachers.

Source: TALIS 2013 and OECD calculations.
B. Access to and participation in induction programmes and mentoring activities

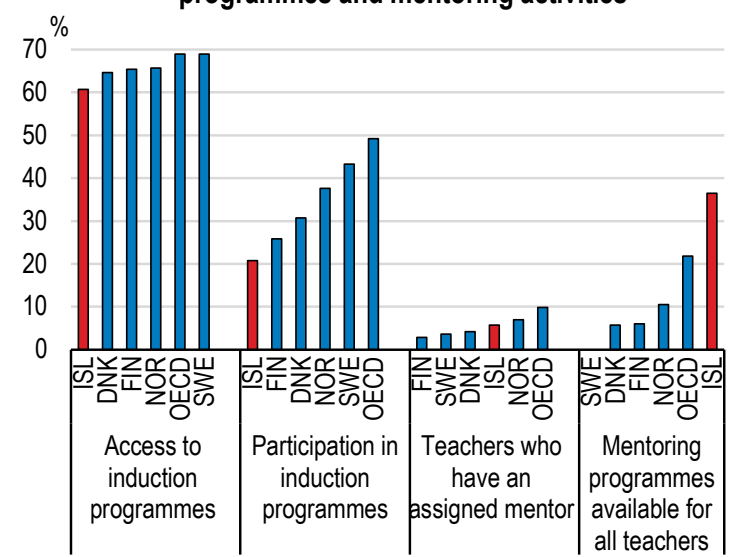

D. Teachers who never received formal appraisal and outcomes of teacher feedback

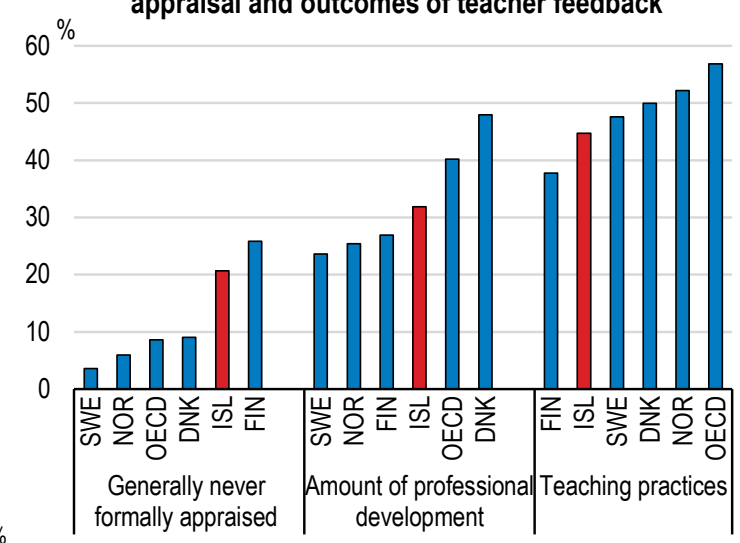




\section{Reducing inequalities in education quality}

A quarter of the schools covered by the PISA sample (120 schools in total) are small, below 100 students, and are located mostly (80\%) in rural areas (Box 1) (Figure 12). This structure serves regional needs but also raises challenges to the equitable distribution of educational resources and quality services across the country. Small schools in rural areas in particular, accounting for $40 \%$ of the PISA school-sample, may face additional obstacles in providing high quality education due to low population density and geographic isolation (Echazarra and Radinger, 2019 [23]).

Figure 12. Many compulsory schools are small, 2015

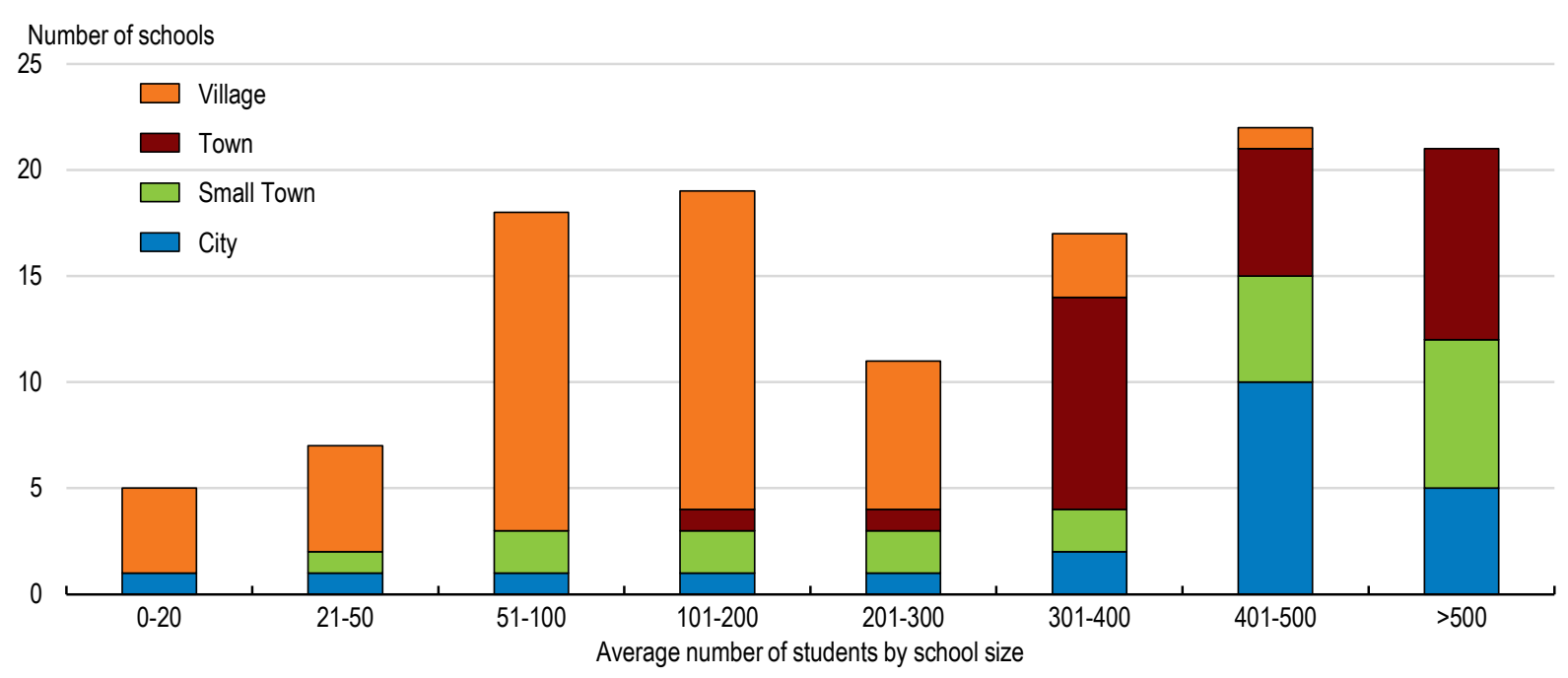

Source: PISA 2015

StatLink 제피 https://doi.org/10.1787/888933996657

Disadvantaged schools (i.e. those at the bottom quarter of school socio-economic profile) and rural schools in Iceland tend to have relatively more teacher resources compared to their counterparts, on the basis of 2015 PISA results (OECD, 2018 $\left.8_{[16]}\right)$, and are also better equipped (OECD, 2016 $\left.{ }_{[22]}\right)$. Such schools, however, are more likely to suffer, according to principals' reports, from teacher shortages and absenteeism, and inadequate and poor quality staff. Objective indicators, such as the share of teachers with a university degree in science, and that of fully certified teachers, show a gap at the expense of rural and disadvantaged schools. This is unfortunate, as studies conclude that students taught by teachers holding a subject-specific certification do better in that subject (OECD, 2018 $\left.{ }_{[16]}\right)$.

Well-designed incentives to attract qualified teachers to less advantaged or geographically isolated schools are important. What is more important, however, is to ensure that school funding mechanisms focus on quality and outputs rather than inputs, while ensuring effective evaluation schemes and safeguarding high equity in education. Under current arrangements there are no formal links between future resources of individual schools or local authorities and past educational performance (Ministry of Education, Science and Culture, 2014[24] $)$. A report by the National Audit Office proposed that funding to municipalities through the Municipal Equalisation Fund should take into account improvements in quality (The Icelandic National Audit Office, 2008 ${ }_{[25]}$ ). 
An effective funding system is vital for the implementation of inclusive education policy. An external audit report assessed that the current funding mechanisms and the resource allocation framework are neither equitable nor efficient, with much scope for providing resources that can be used flexibly to support all the learners (European Agency, 2017 [26]). "Grey-zone pupils", i.e. those who are recognised by the school teams as having an additional need, but not sufficiently severe to qualify for extra funds, were flagged as a particular concern by the report as such students are often seen as "missing out", with their needs not being met. Developing flexible resource allocation mechanisms therefore is very important, as it was also recommended by the external report. The role of the funding mechanisms and the Municipal Equality Fund are currently under evaluation in the context of the Education Policy 2030 review.

Internal and external evaluations and monitoring of school operations are part of the legislative framework for education in Iceland, and publishing information is an established practice. All schools are required to have in place a system of internal evaluation and make the results publicly available, along with a reform plan. The Directorate of Education conduct external evaluations for compulsory schools in co-operation with municipalities, and for upper secondary education through independent evaluators. The results of such assessments are also made public. Evaluations, however, are not frequent but rather take place every 10 years (or dependent on risk assessment) in the case of compulsory schools and 5 years in upper secondary schools. The authorities also assess school performance on the basis of results of student national tests at grades 4, 7 and 9/10, but standardised tests at the upper secondary level and mechanisms to compare student assessments between schools are not in place.

More effective evaluation and assessment are essential for improving education outcomes, while also increases transparency. The 2017 report by the external audit (see above) highlighted, in particular, the need to focus evaluation standards on quality and classroom creativity, rather than school management practices, as is currently the case (European Agency, 2017[26] $)$. Local authorities could also consider using the results of external evaluations as an instrument to allocate funds across schools, which would enhance accountability. In addition, to strengthen the monitoring of education outcomes, the frequency of external school evaluations should be increased and cover as much schools as possible. A well-trained and adequately staffed body of external assessors is very important in this regard, as are clear and consistent guidelines for the evaluation process.

Last but not least, based on best practices, Iceland needs to develop an integrated assessment and evaluation framework bringing together student assessment, teacher appraisal and school evaluation (OECD, 2016 $\left.6_{[1]}\right)$. This would help to create synergies for learning. Putting in place an efficient formal teacher appraisal system is a precondition for such an integrated approach.

\section{There is scope for better skills matching and a more rigorous analysis of skills needs}

\section{Evidence suggests the presence of skills gaps}

Iceland seems to face skills imbalances, although comprehensive data to assess their actual size are not yet available. Evidence based on the OECD Skills for Jobs database indicate, in particular, the presence of skills shortages, especially in occupations requiring high skills which account for most of Iceland's employment growth over the past decade and a half (Figure 1, Panel E). This occurs despite a highly educated workforce in terms of the number of tertiary graduates (Figure 13, Panel C). Detailed sectoral OECD data suggest that 
professional, scientific and technical activities, financial and insurance, and information and communication are the occupations suffering most from skills shortages (Figure 13, Panel A). While these data may not reflect the latest developments, they are indicative of sectoral skills needs.

Figure 13. Many sectors appear to face skills shortages

\section{A. Shortage occupations by industry}

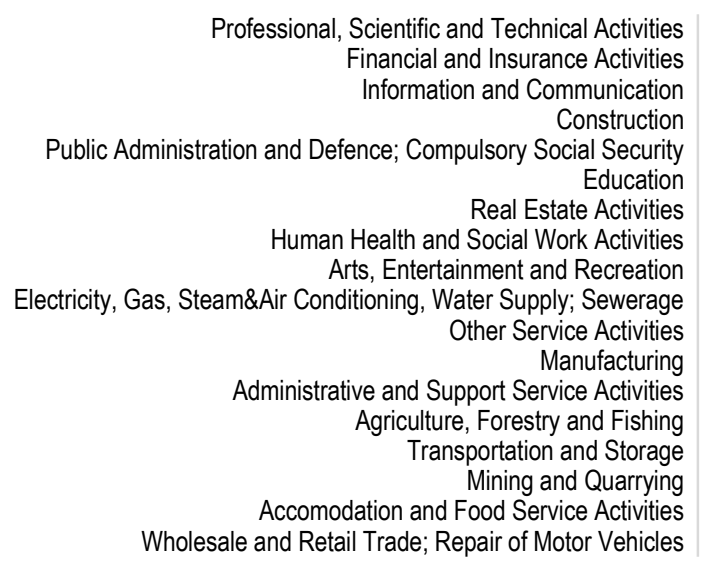

$-0.4$

\section{B. Degree of labour market imbalances across} countries

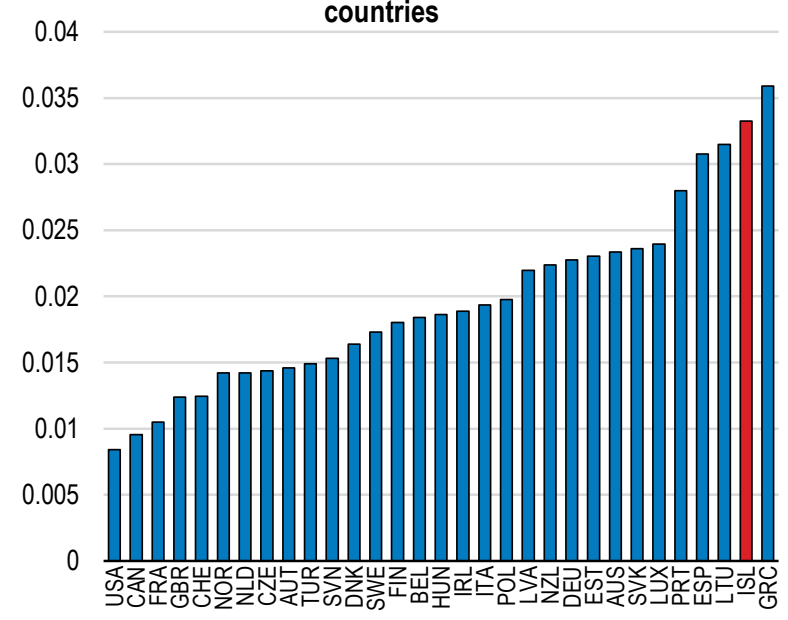

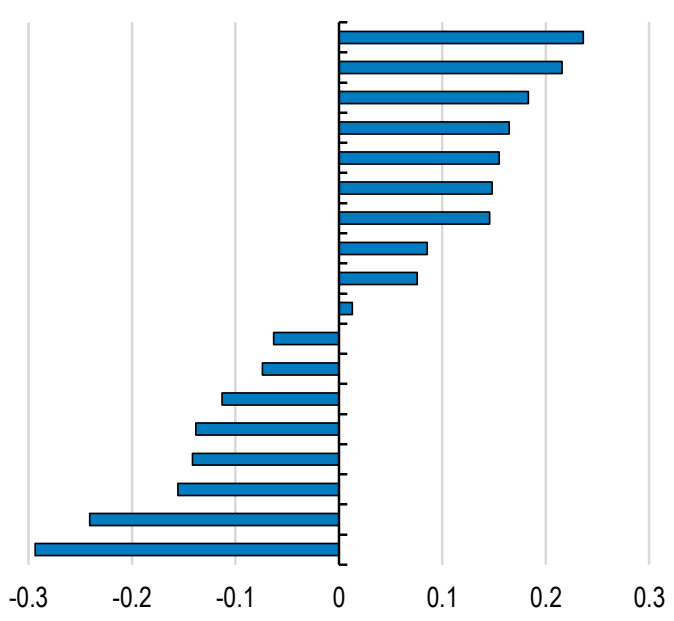

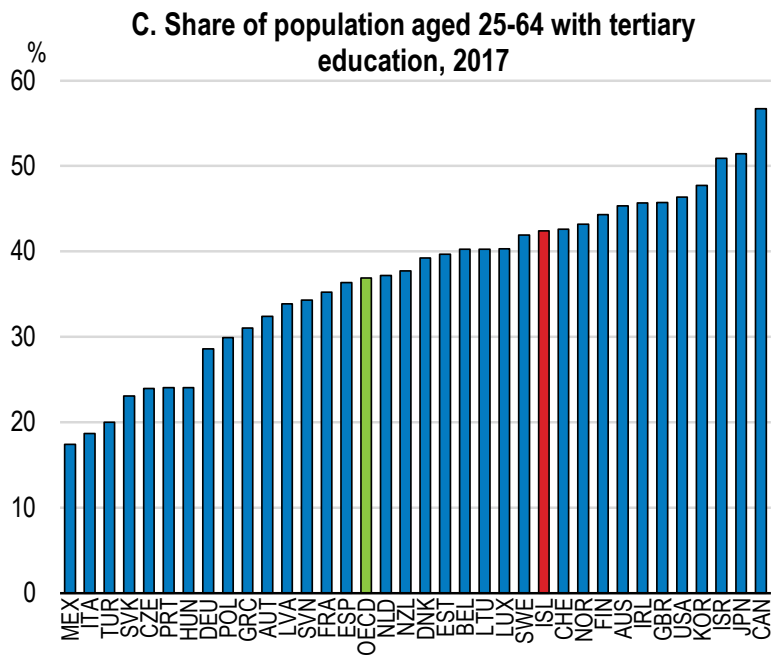

Note: The data in panels A and B refer to 2012. No recent data are available. Sector shortages occur when firms struggle to find appropriate talent. Surplus arises when the supply of workers in that sector exceeds demand. Results are presented on a scale that ranges between -1 and +1 . The maximum value reflects the strongest shortage observed across countries, sectors and skills dimensions.

Source: OECD Skills for Jobs database (2018); OECD Education at a Glance 2018 and OECD calculations.

\section{StatLink 케s $\mathrm{https://doi.org/10.1787/888933996676}$}

There is also evidence of skills mismatch, both in terms of qualifications and field-of study, with many workers being over-qualified for the jobs they do, or employed in a different field from what they have studied (Figure 14). Although some degree of skills imbalances and qualification mismatch is expected in a dynamic economy, and shortcomings in the data need to be acknowledged (Institute of Economic Studies, $2018_{[27]}$ ), the results still flag 
scope for a better allocation of resources and higher productivity (Figure 13 and Figure 14). Looking at the possible drivers of such imbalances, structural changes in certain industries, notably tourism and financial sector, large wage differentials between the fast growing occupations and a sizeable influx of foreign labour over the past 15 years can all play a role. These may be reinforced by the challenges facing the domestic education system to adapt to changes in labour market demands because of the lack of a strong vocational stream and a quantity-oriented tertiary education, as well as shortcomings in lifelong learning programmes, as discussed below.

Figure 14. Skills mismatch could be reduced
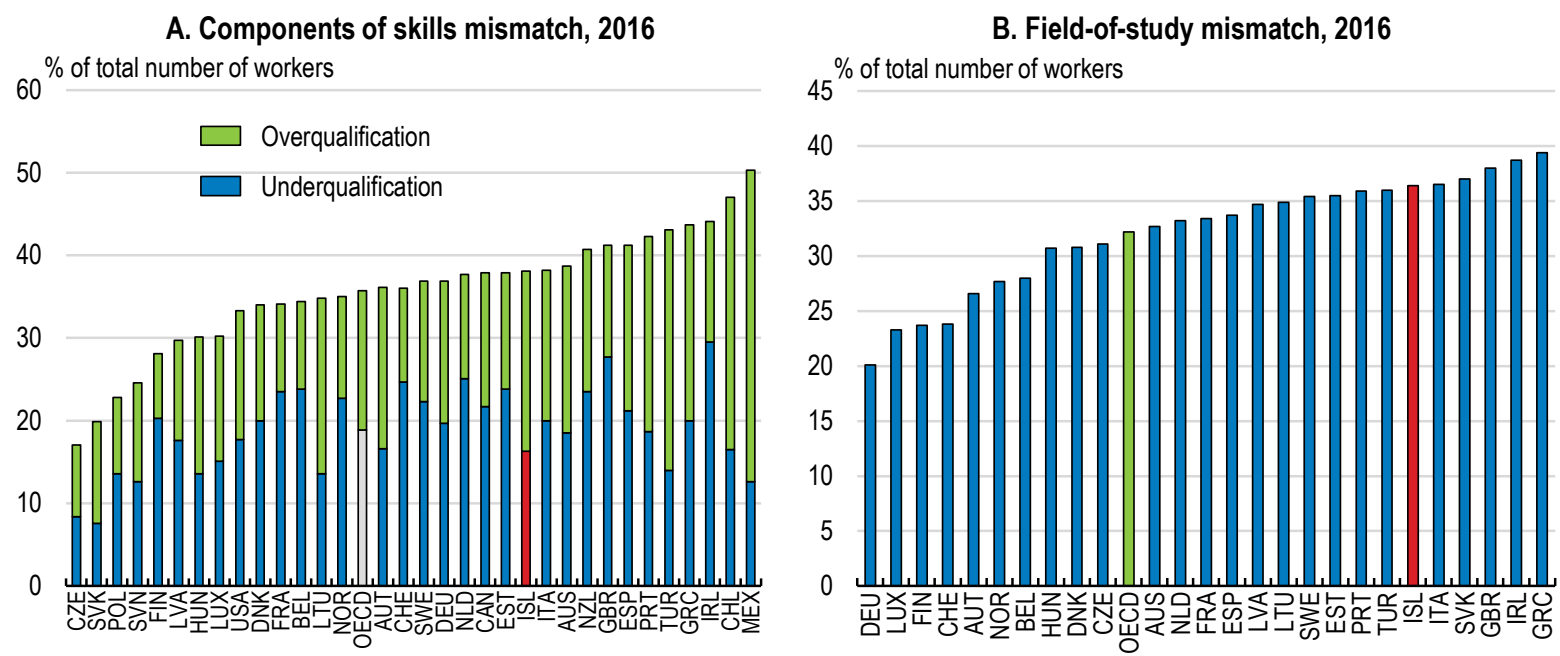

Note: Qualification mismatch describes a situation for which a worker has qualifications that exceed (overqualified) or does not meet (under-qualified) the ones generally required for the job. Field-of-study mismatch arises when workers are employed in a different field from what they have specialised during their education.

Source: OECD Skills for Jobs database (2018).

StatLink הints https://doi.org/10.1787/888933996695

\section{Developing tools to assess and anticipate skills needs}

Skills assessment and anticipation exercises are used by many OECD countries to inform policy planning in a range of areas including education and migration. The outcomes of such exercises can also steer individuals' choices with regard to training and career pathways. Countries differ largely with respect to the range of measures employed to analyse skills needs, as well as the forecasting horizon. Some countries, such as Australia, use a variety of tools including surveys, quantitative forecasting measures, sectoral studies and qualitative methods $\left(\mathrm{OECD}, 2018_{[28]}\right)$. Long-term scenarios are relatively common in Nordic countries. Norway, for instance, carries out 20-year general occupational forecasts and Denmark's model evaluates scenarios for up to 100 years in the future (OECD, $\left.2016_{[29]}\right)$.

Iceland lacks a well-developed national database on skills mismatch and reliable long-term projections for the skills demanded. Forecasting and analysis of industry skill-needs were based, so far, on various ad-hoc studies rather than a systematic approach. As a positive step a committee, set up by the government, has submitted in 2018 a report focusing on the organisation, scope and requirements for a regular monitoring of skills demands. Progress 
in this domain is essential. The methods and tools to assess and anticipate skills needs should rely on several sources of information, both quantitative and qualitative if feasible, in line with best practice.

\section{Addressing skills imbalances}

\section{Strengthening the vocational pillar}

The VET system has relatively low participation rates and lacks a well-integrated workbased component (OECD, 2012[30] (Figure 15, Panel A). While the employment rates of 24-34 year-olds are high in the current conjuncture, even in the case of less educated youth, a more effective VET system is vital to reduce skills-mismatch and also prepare Iceland to meet future skills demands (Figure 15, Panel B). A stronger vocational pillar would also help to address Iceland's dropout challenge. Around 20\% of young adults (aged 25-34 years) did not have an upper secondary qualification in 2017, below the share a decade ago, but still above the OECD average and peer countries (Figure 16). Entrants in vocational programmes appear to be affected more by school dropouts and slow study progression than their counterparts in the general programmes probably because of the weaker core skills VET students have built up at the end of compulsory education. Although many dropouts return to education and training in their late twenties and thirties, which helps them to strengthen their skills, early school leaving still represents an impediment to the development of solid cognitive skills, according to OECD research (OECD, 2018 [31]). 
Figure 15. Participation in VET needs to increase, despite good job outcomes

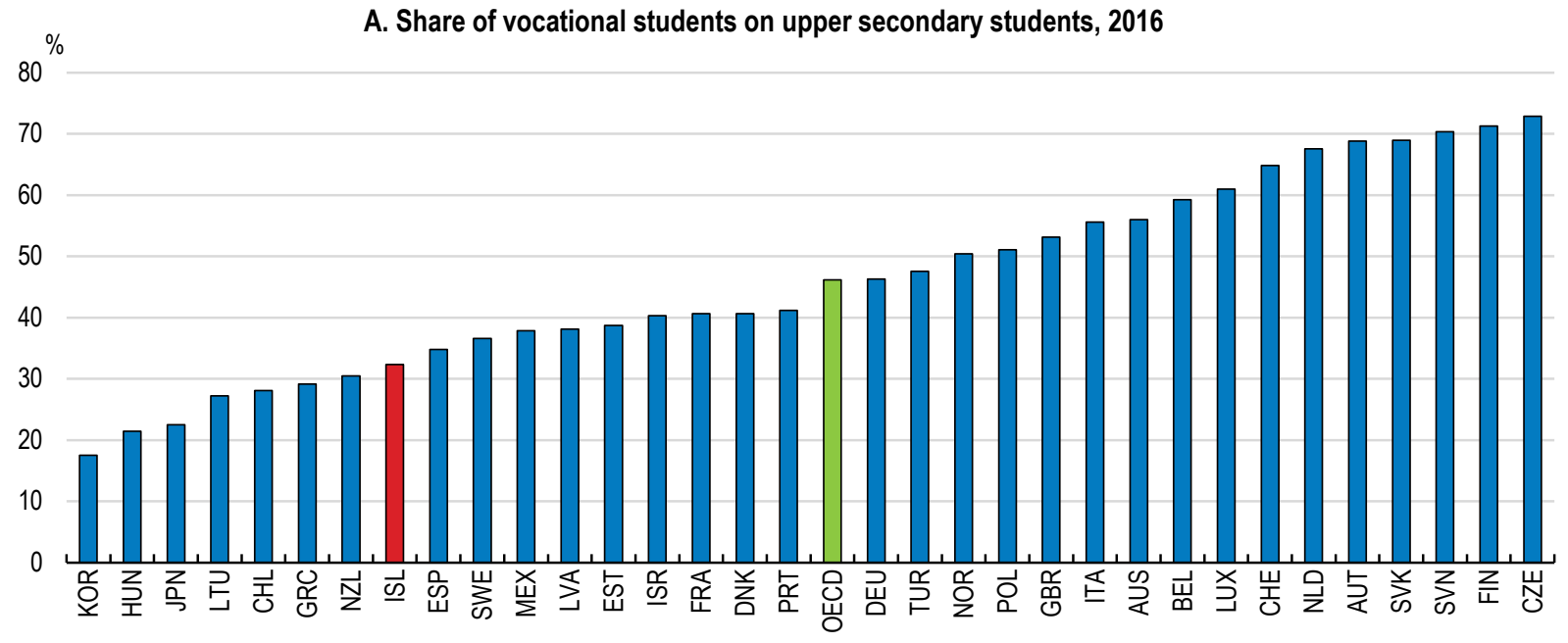

B. Employment rates of 25-34 year-olds, by educational attainment 2017 $\%$ of all $25-34$ year-olds

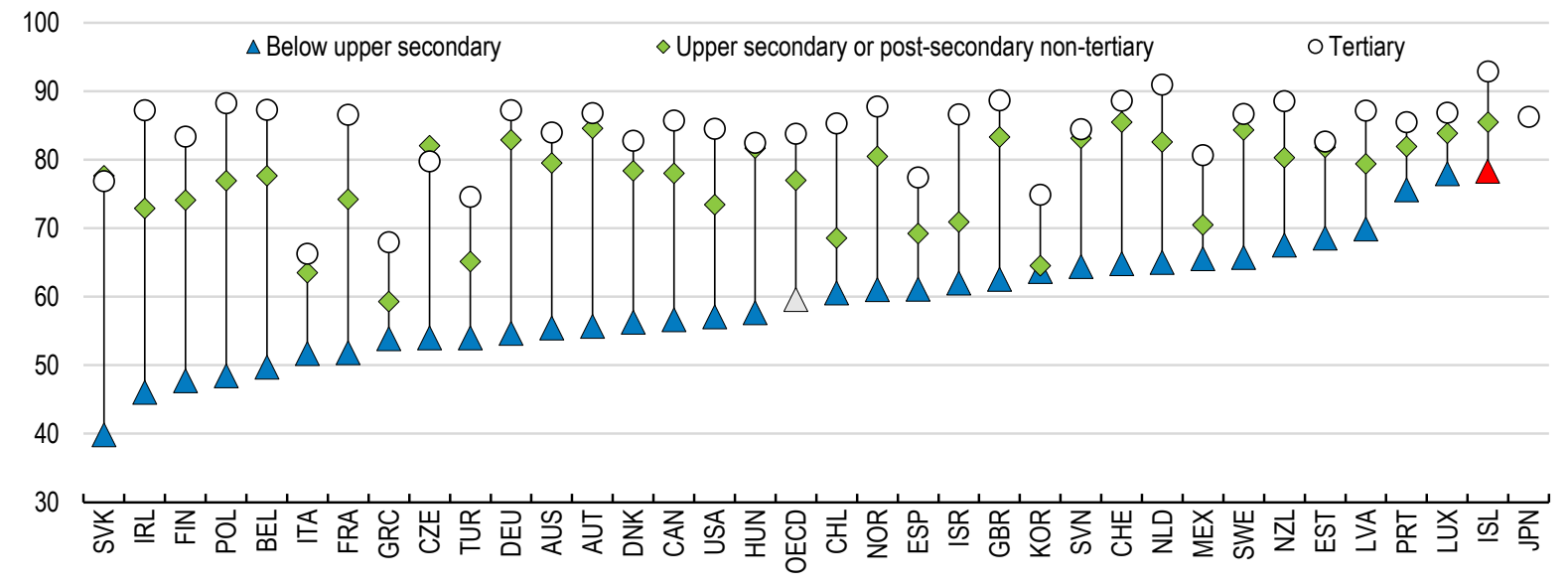

Source: OECD Education at a Glance 2018.

StatLink 켚 https://doi.org/10.1787/888933996714 
Figure 16. School dropouts and late completions affect VET students more

A. Percentage of 25-34 year-olds with below upper secondary education as the highest level attained

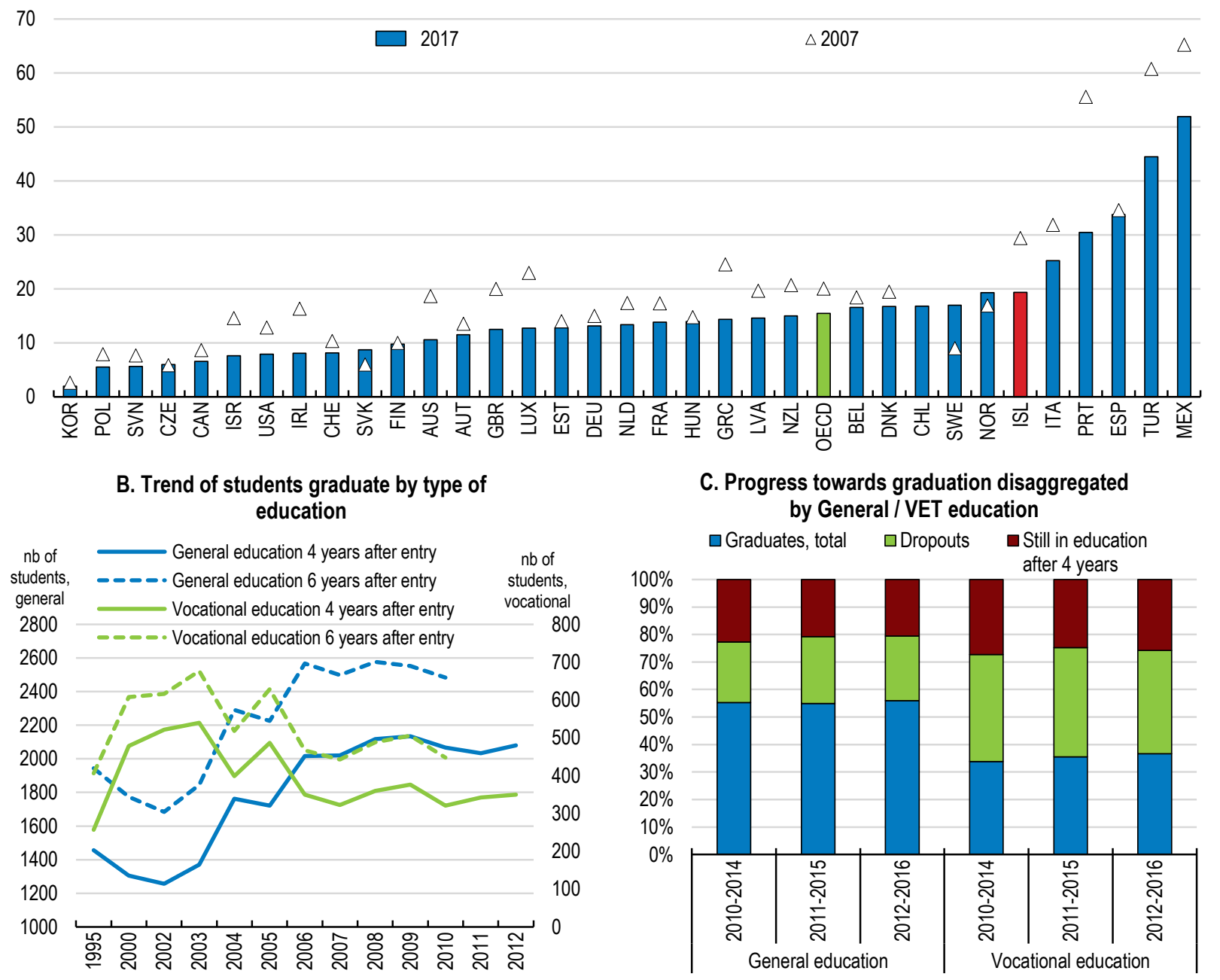

Source: OECD Education at a Glance 2018; Statistics Iceland.

StatLink त्ञाIs https://doi.org/10.1787/888933996733

Improvements in quality are essential for a more effective and attractive VET system. Enhancing teachers' technical competencies through training programmes in the business sector, and regularly updated curricula in close collaboration with social partners, are prerequisites. Strong career guidance and good quality information on graduates' labour market outcomes are also critical to enhancing VET's attractiveness, as are more solid pathways from vocational to tertiary education. There are no separate tertiary VET institutions at present (see below).

Greater co-ordination and reduced complexity would strengthen the vocational system. Plans by the authorities to re-assess the functions of the numerous committees ( 70 committees, comprising around 350 members) involved in the VET administration, and define clearly their roles and tasks, are welcome steps towards a more co-ordinated governance and should go ahead. A well-functioning occupational committee, which acts as an advisory and coordinating body, is key for the effective oversight of the sector 
(Musset and Valle, 2013 ${ }_{[32]}$ ). The VET system should also become less complex in terms of programmes offered through a careful streamlining based on a well-evidenced assessment of their outcomes. It is important that less complexity does not come at the expense of diversity and innovation.

To equip students with solid practical skills, the school- and work-based learning components of VET need to be well-integrated. This is the case of countries with a wellestablished vocational education track such as Denmark, Germany and Switzerland. The length of workplace training provided as part of upper secondary vocational programmes varies significantly in Iceland, from $0 \%$ to $80 \%$ of the total duration of VET studies. This implies that some vocational programmes are purely school-based. More importantly, the apprenticeship training is not an integrated part of the school studies, with the apprenticeship system associated with traditional trade professions being the only exception. In other words, schools do not provide work-based positions; rather, VET students have to search them and apply to companies of interest. In certain occupations, it can be very difficult to find a placement (Steafansdottir, 2014 ${ }_{[33]}$ ). Around half of the Icelandic students in VET appear to take the apprenticeship route, according to the EU data. This however seems to be restricted to the traditional trade professions where the system entails an effective balance between school and work-based training and clear options for further upskilling, including as master craftsman (Musset and Valle, 2013 [32]).

The well-developed apprenticeship model associated with traditional trade professions should be expanded to other VET fields, introducing opportunities for workplace learning to all vocational programmes. A strong apprenticeship system in service sectors, such as tourism and information technology (IT), would be particularly beneficial given the importance of such sectors in the economy. The structure of VET programmes could also be examined, particularly with regard to the appropriate length of the school-based part. The duration varies across countries. In Norway, for example, two years of school-based learning precede two years of work-based placement, while in Denmark the school-based part accounts for one-third of the VET programmes (Jorgensen, 2015 34$]$ ). The quality of the apprenticeship system could be further strengthened by moving from a time-based to a competence-based scheme, linking success to knowledge acquisition, as for instance in Australia and the United Kingdom.

Complementary measures that encourage participation by business may also be necessary. While employers can apply for grants from the Apprenticeship Fund to subsidise the provision of work-based training, such grants are not guaranteed and are limited in number and quantity. Broadening the options of financial support would therefore be beneficial including through cost-sharing mechanisms or joint apprenticeship programmes available in some countries $\left(\mathrm{OECD}, 2018_{[35]}\right)$. Increased capacity of firms to provide workplacebased training for vocational students is also of high importance.

\section{Harnessing skills for a knowledge- and innovation-driven economy}

Iceland has two universities among the world's top, which is a welcome development given the relatively small size of the domestic tertiary sector, but in terms of score performance it ranks below its Nordic peers (Figure 17). The tertiary education system could become more quality-oriented. Current incentives make it attractive for universities to focus on enrolments, rather than performance, as funding is allocated across institutions on a perstudent basis (Box 1) (Chapter 2 of the 2019 OECD Economic Survey of Iceland). This raises concerns that the funding system prompts a bias towards inexpensive courses and popular studies. In addition, the current arrangements do not promote differentiation of 
institutional profiles as they provide similar incentives for all institutions, driving homogeneity. As a positive move, a Quality Board was established some years ago, with the second evaluation cycle underway.

Figure 17. Tertiary education performance could be enhanced
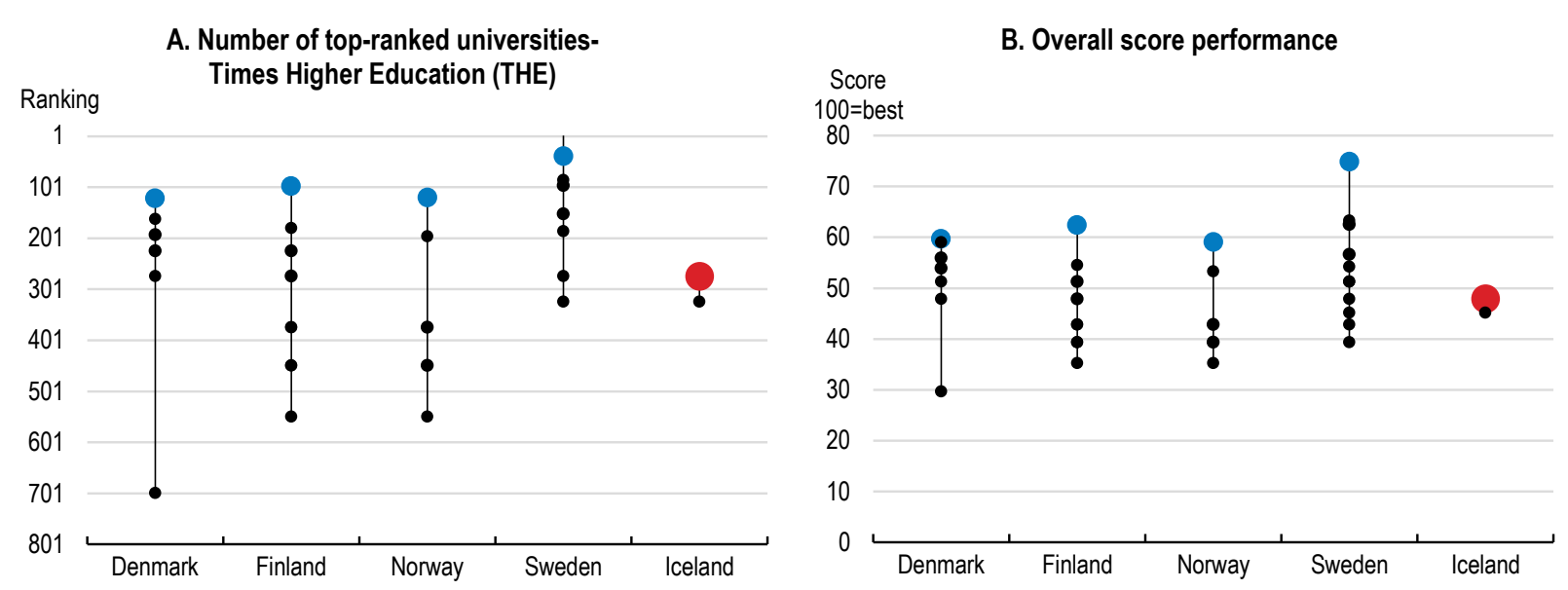

Note: The Times Higher Education World University Rankings are the only global performance tables that judge research-intensive universities across all their core missions: teaching, research, knowledge transfer and international outlook, using 13 performance indicators.

Source: The 2019 Times Higher Education World University Ranking.

StatLink iㅔs https://doi.org/10.1787/888933996752

An ongoing reform of the university funding system aims to shift the focus from quantity to quality and outcomes. This is appropriate. Performance indicators, including the introduction of research criteria (both in terms of outcomes and laboratory/equipment intensity), should play a more dominant role in the new funding scheme to ensure higher quality outcomes. Consideration could also be given to the introduction of multi-year performance agreements between the government and each higher education institution, aiming to incentivise differentiation and quality improvement. A recent reform in Norway moved towards this direction (OECD, 2016 $[36])$. Agreements would be valid for a specific period and portion of the funding to an institution would be linked to them. The design of such agreements could be the outcome of a dialogue with the universities. The new funding system should also take into account the gender aspect. A recent project by the University of Iceland, as part of an international project (GARCIA), showed that policies and systems of distributing funds have different impact on male-dominated and female-dominated fields at the university, resulting in funds not being distributed in a gender equitable way (Steinpórsdóttir et al., 2016 ${ }_{[37]}$ ). Choice of studies is very-gender disaggregated, with women being overrepresented in studies that have lower pay after graduation. This can affect adversely economic equality between genders after graduation. Ensuring gender equality in research is now an important priority in the European Union.

Explicit incentives under the current funding system to align the provision of tertiary education to labour market demands are generally missing. A weak response of skills development to labour market needs (Figure 14) can reflect a number of factors that go beyond funding mechanisms. These include, for instance, an inadequate counselling, and/or tight labour market conditions that make it easier for youth to find a job. The compressed wage distribution in Iceland could be another reason. Still, establishing a more 
direct link between the tertiary funding system and labour market demands would be advisable. Differentiated awards to institutions could be considered, for instance, for those courses that provide skills corresponding closely to the labour market needs. Such a reform hinges upon the development of a rigorous methodology for assessing labour market needs and solid data on graduates' employment outcomes. Appropriate data dissemination and effective career guidance are also important for a balanced skill-mix.

Iceland does not have a tertiary VET sector. All higher education institutions have the status of universities, but some offer vocational programmes (Box 1). Providing an appropriate mix of vocational and academic skills is essential in an era of fast changing labour demands. A pilot project underway aims to develop post-secondary/tertiary VET programmes in cooperation with the universities. The attractiveness of such programmes would increase if students from tertiary VET programs were allowed to enter a post-graduate course without further studies.

In fostering flexible skills, an alternative option to enhancing the VET-content of university programmes would be to move to a "dual" tertiary system by introducing separate VET institutions. This is the case, for example, in Austria, Germany, Switzerland, as well as Denmark and Norway. In choosing the appropriate option, one needs to take into account the range of potential study and progression opportunities under each option, as well as the size of the tertiary market to avoid overcrowding and further fragmentation, and also, increased complexity. While there is no "optimal" size, an important challenge is to ensure that institutions are of sufficient size to promote quality. Very small-size institutions may also lack a "critical mass" in research (OECD, 2016[36]).

Education and skills for innovation are essential for embracing the digital age. Boosting STEM (science, technology, engineering and mathematics) skills, especially among women who are under-represented in STEM disciplines, is important (Figure 18). Iceland ranks below the OECD average in terms of tertiary graduations from such fields. At the same time, care is needed at developing STEM-related policies as not all STEM disciplines have strong labour demand. Moreover, there is growing consensus that policies should go beyond STEM subjects in building an innovation-rich skills base. This is underscored by the OECD's Innovation Imperative report (OECD, 2015[38]). For instance, some categories of arts can have a high innovation-enhancing value. 
Figure 18. Relatively few students graduate from STEM fields

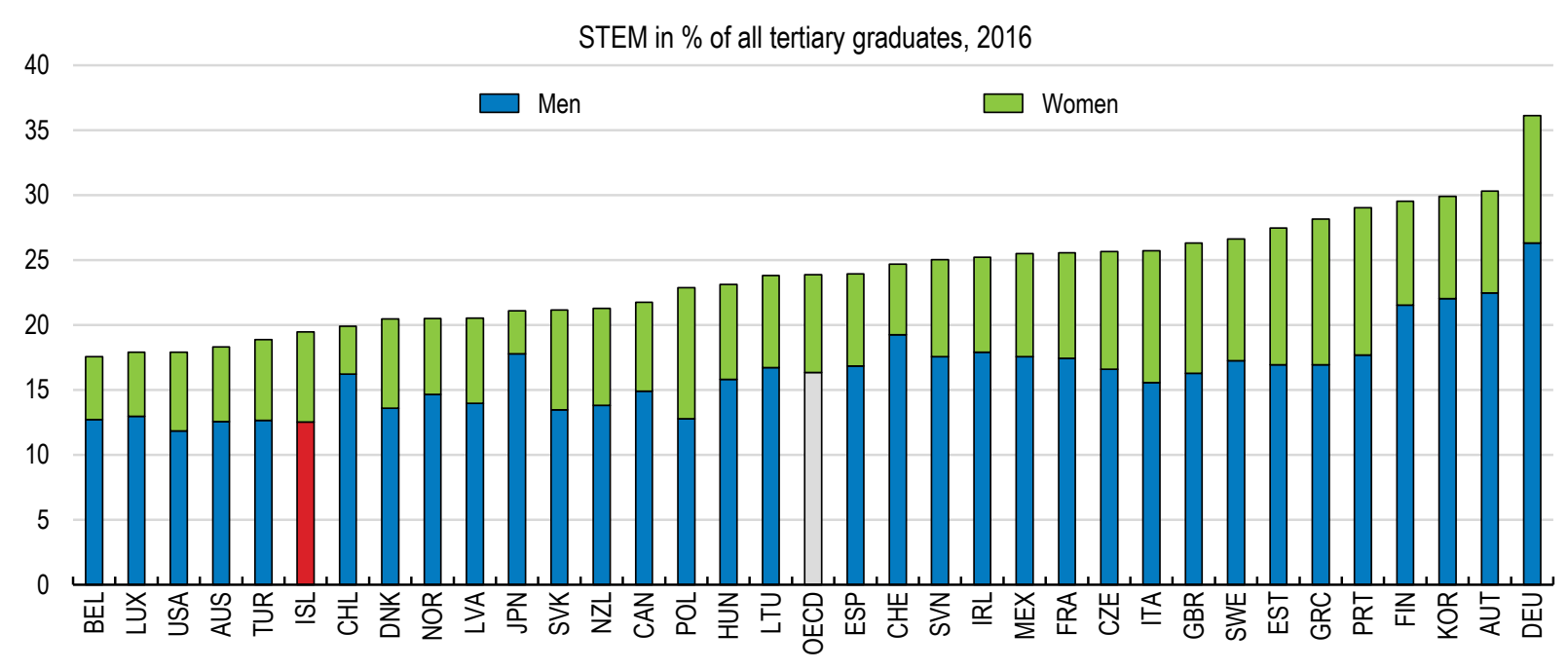

Source: OECD Education at a Glance 2018.

StatLink त्राज ht htps://doi.org/10.1787/888933996771

Entrepreneurship education can enhance innovation-relevant skills, while equipping students with broader competences such as creativity and collaborative skills that are transferable between jobs (OECD, 2019 $\left.{ }_{[39]}\right)$. Steps towards promoting entrepreneurship skills are welcome. The Reykjavik University, for instance, provides a business development course (Entrepreneurship and Starting New Ventures) in the first year of studies and encourages students to work on projects with industry. Strengthening the supply of entrepreneurship education at tertiary as well as lower levels of education is important. In the Netherlands, for instance, all Universities and Universities of Applied Science offer entrepreneurship units in degree courses (OECD, 2017 $\left.{ }_{[40]}\right)$. At the same time, teachers need to have initial training in entrepreneurship and continuously update their knowledge in the field. Developing entrepreneurship indicators to monitor progress and impact would provide useful insights for policy making.

There is scope to strengthen the collaboration between research and business sectors on innovation. Collaborative research is an increasingly recognised channel of knowledge transfer and skill development (OECD, 2015 $\left.{ }_{[38]}\right)$. The technology clusters, especially with respect to fishing technology, provide successful examples of collaboration. However, collaborative research remains relatively low in international comparison, even in the case of large firms, with a little mobility of researchers between the business and university sectors (Figure 19). The private co-funding of public R\&D expenditure is around half the EU average, according to available data (European Commission, $2017_{[41]}$ ). 
Figure 19. Collaborative research could be strengthened

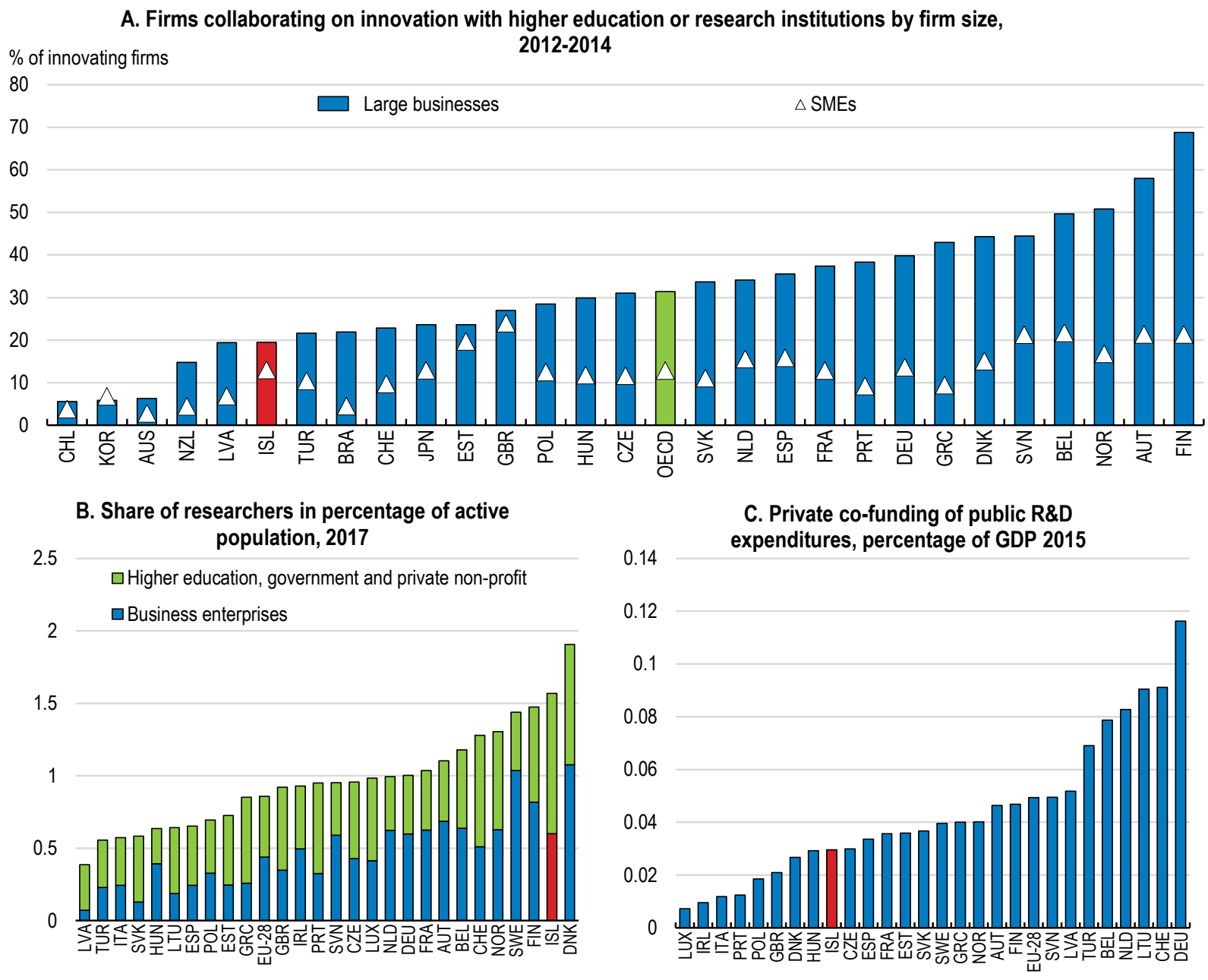

Source: European Innovation Scoreboard 2018 Database, Eurostat database.

StatLink तilst https://doi.org/10.1787/888933996790

Collaborative research can be improved through measures that encourage universities and business to engage more with each other. These include, for instance, innovation vouchers granted to SMEs to buy industrial or applied R\&D from selected public research institutions. A number of countries use innovation vouchers, although the design differs widely across them $\left(\mathrm{OECD}, 2010_{[42]}\right)$. Clearly defined eligibility criteria and a close monitoring of the impact of the vouchers on the collaboration between research and business sectors are necessary for successful outcomes.

Giving more weight to collaborative research when allocating funds to universities could be another option. A move in this direction would require encompassing in the university funding model a set of collaboration-related criteria, including the number of patents and joint academia-business publications. Such a reform would also help to improve the management of intellectual property (IP) created by the universities. While Iceland is a "strong" innovator, according to 2017 European Innovation Scoreboard, intellectual assets remains an area of weakness, with PCT patent applications falling below the EU 28 average (European Commission, 2017 ${ }_{[41]}$ ). A technology-transfer office (TTO) was established in 
2018 with the participation of all universities. Strong skills and capacities in the management of IP are essential for the effectiveness of the TTO.

\section{Ensuring lifelong learning for all}

Participation in adult learning is high in international comparison, according to the survey data, even though below the levels in other Nordic countries (Figure 20, Panel A). The right to continuing education and training is specified in collective agreements in Iceland, with available funding for those participating (Andersen, Hougaard and Ólafsson, 2011 ${ }_{[43]}$ ). Education institutions also offer continuing courses, leading to diplomas and/or further studies. Overall, Icelandic workers have the flexibility of entering and re-entering the education and training system, which implies a wide-range of lifelong learning opportunities.

\section{Figure 20. Participation in lifelong learning}

Per cent of population aged 25-64 participating in education and training in the preceding four weeks, 2018

\section{A. Participation in life-long learning}

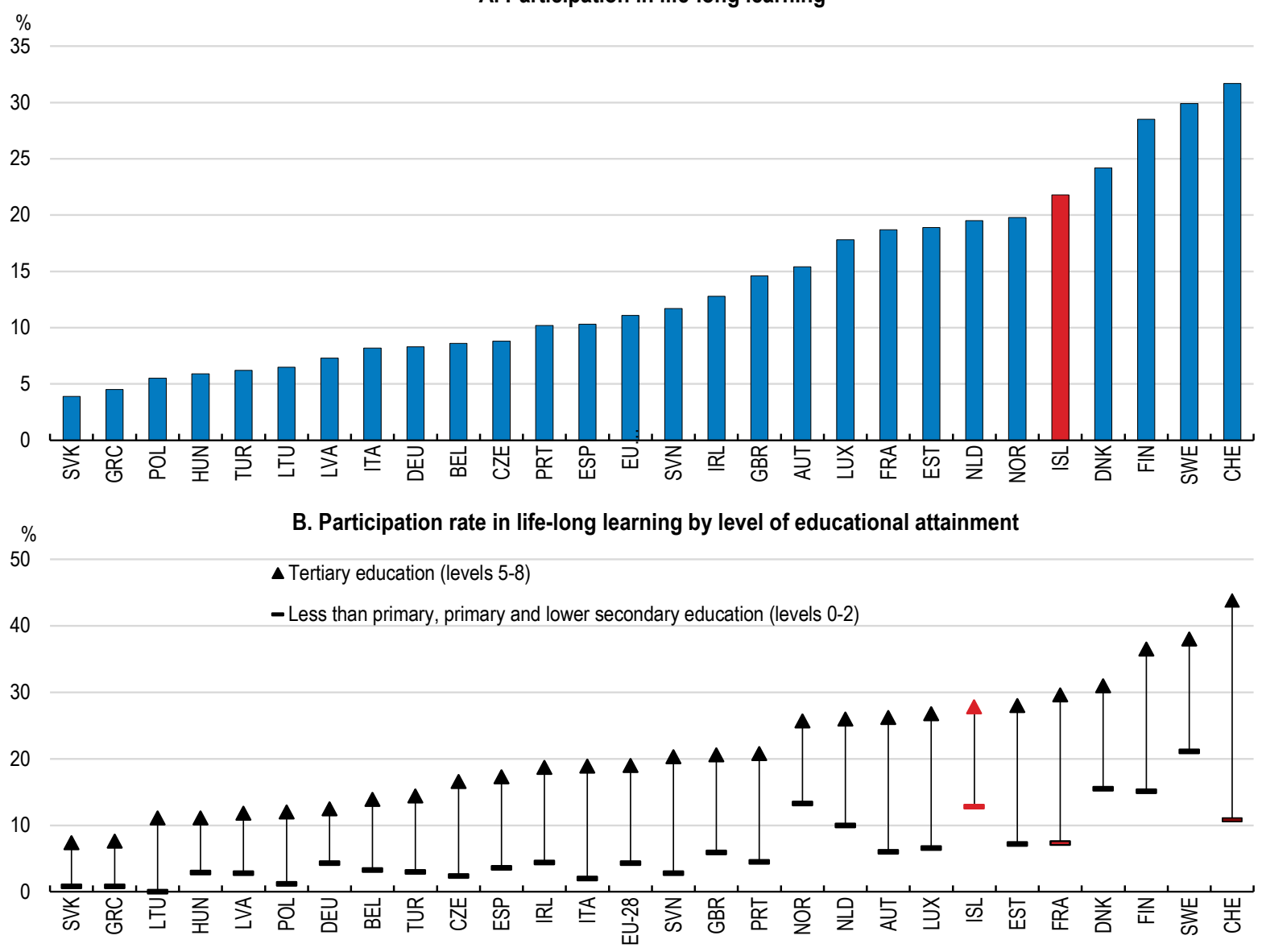

Source: Eurostat Labour Survey 2018.

StatLink त्ञाI

Still, disaggregated data suggest that, in common with other countries, lifelong training is generally concentrated in certain groups and in particular the more educated ones. Those 
having completed only compulsory education lag behind (Figure 20, Panel B). This is unfortunate as less educated workers could benefit substantially from taking part in adult learning, including by becoming more resilient to future labour market changes. The relative smaller engagement of the less advantaged groups to adult learning could be explained by a number of factors including weak incentives, lack of support by the employers and limited awareness about the potential benefits from pursuing continuing education and training $\left(\mathrm{OECD}, 2017_{[44]}\right)$. As a positive step, the government has introduced skills assessment schemes to facilitate re-entry into the formal school system for workers that lack upper secondary qualifications, by evaluating work experience and acquired skills.

A variety of financial incentives are provided by OECD countries to encourage participation in adult learning of under-represented groups. This is justified, as workers and firms may not fully internalise the need for further investment in skills. The financial incentives provided usually by the OECD countries include subsidies, such as vouchers and grants, and tax incentives in the form of a tax allowance or tax credits. Some countries, for instance France and the Netherlands, have introduced individual learning accounts (ILAs) (OECD, 2019 $\left.{ }_{[45]}\right)$. Such schemes attach training rights to individuals, rather than jobs, to fund future education and training and include accounts where time and/or savings for training are accumulated over time (OECD, 2019 [46] $)$. ILAs have received increasing attention in recent years as they allow for portability of the training rights between jobs and also employment statuses, facilitating career transitions. A careful design of financial incentives is vital for achieving better targeting and reducing deadweight costs. Welldisseminated information on available lifelong learning programmes and effective career counselling are necessary complements to these measures, if the strategy is to be successful.

\section{Making better use of existing skills}

\section{Active labour market policies}

Iceland's favourable labour market conditions make the implementation of extensive active labour market policies a less pressing issue (Andersen, Hougaard and Ólafsson, 2011 $1_{[43]}$ ). A safety net is required, however, to cope with potential cyclical downturns in the future and concomitant labour market adjustments. The sharp increase in the unemployment rate during the crisis, from approximately $2 \frac{1}{4} \%$ of labour force in 2007 to $7.6 \%$ in 2010 , and a rise in the share of disability pensioners below retirement age by around half percentage point over the same period, reinforces this view. Moreover, long-term unemployment remains well above the pre-crisis levels (9.2\% of those unemployed in 2017 compared to $4.1 \%$ in 2008). Effective activation policies need therefore to remain on the government agenda, helping the unemployed to find quality jobs and upgrading skills where appropriate. A well-functioning and responsive Public Employment Services (PES) is a key element of such a strategy.

The Icelandic PES (Vinnumàlastofnun) has taken significant steps toward modernisation in recent years, as assessed by an external audit, but further improvements are needed (European Commission, 2018[47]). Iceland's PES still lags behind those in other Nordic countries, especially Denmark and Sweden (European Commission, 2019 [48]). Ongoing reforms aim to strengthen PES performance management and enhance the efficiency and transparency of the process. Measures to this end include the introduction of specific strategic objectives under the "Three Year Strategy", which is an important step towards target-setting, and improvements in the PES staff. Ensuring an appropriately skilled staff with competencies in different areas is among the key priorities. Current reforms also aim to upgrade the IT structure of the PES, extending digital services for its customers. This is 
welcome and needs to be completed on time. A digitalised system would enable a greater standardisation of service delivery processes through a better documentation of provided services, increasing transparency. Moreover, such system would facilitate a better mapping of job-seekers needs and prioritisation within groups, promoting more effective activation programmes.

Reforms to modernise the PES should also aim at strengthening the evaluation and monitoring of the provided activation programmes. Systematic data collection on the outcomes of the various programmes, in terms of training and job reinstatement of registered workers, is of high importance. The improvement of performance indicators is on the PES agenda, with some steps already taken to this end. Efforts need to continue. The developed indicators should be simple and easy-to-quantify and focus on key areas, although the difficulties in constructing such indicators should not be underestimated. A rapid progress toward digitalising the PES would facilitate high-quality evaluation analysis and effective monitoring.

\section{Improving financial incentives to work}

Unemployed workers in Iceland, especially from low paid jobs, have weak financial incentives to return to work (Figure 21). Out of work support for jobseekers is comparatively generous. Net replacement rates in unemployment (NRRs) are above the OECD average and remain high especially at long unemployment durations (Figure 22). This, combined with the full withdrawal of the unemployment benefit when taking up a full-time job, can increase the financial disincentives for low-paid workers to take-up a job. While this is not a problem at present as labour market conditions are buoyant, it could affect the speed of return to work in the event of a cyclical slowdown, as highlighted by a previous Survey (OECD, 2011 $\left.{ }_{[49]}\right)$.

Figure 21. High effective tax rates on entering employment
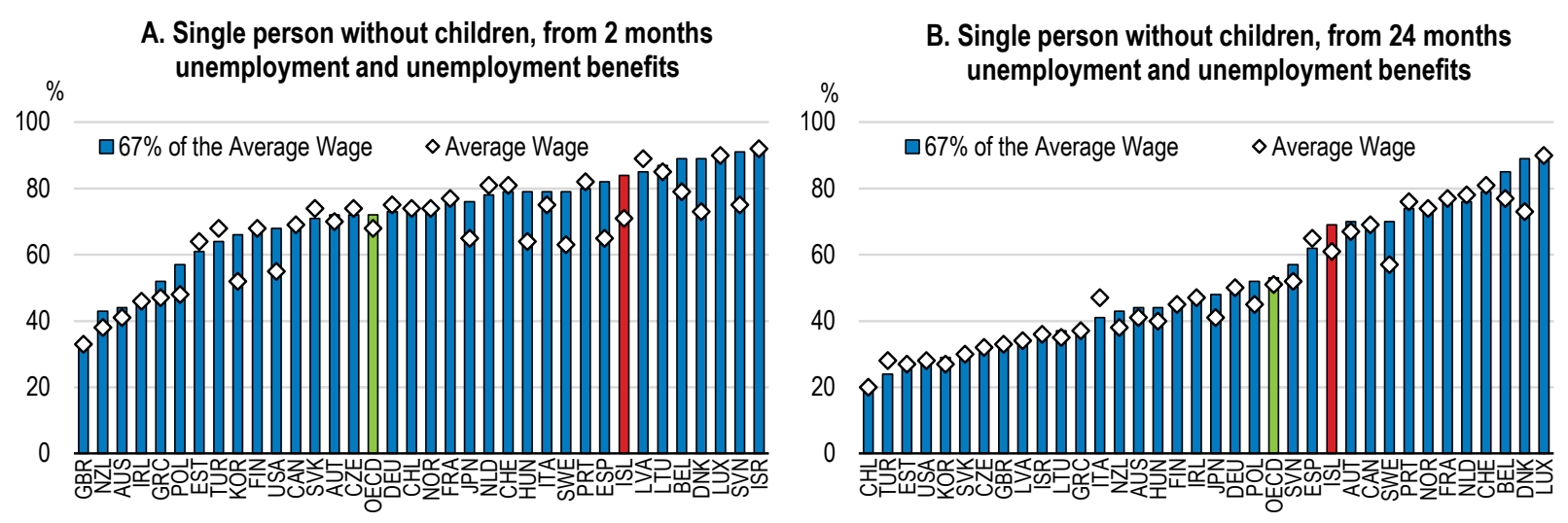

Note: The Effective tax rate on entering employment (or Participation Tax Rate) measures the proportion of inwork earnings that is lost to either higher taxes or lower benefit entitlements when a jobless person takes up employment. This can be interpreted as an indicator of financial disincentives to participate in the labour market. Results refer to a 40-years-old unemployed person with a "long" and continuous contribution history and previous earnings at $67 \%$ or $100 \%$ of the average wage.

Source: OECD, Tax-Benefit model, 2018. 
Figure 22. Relatively high net replacement rates may reduce work incentives
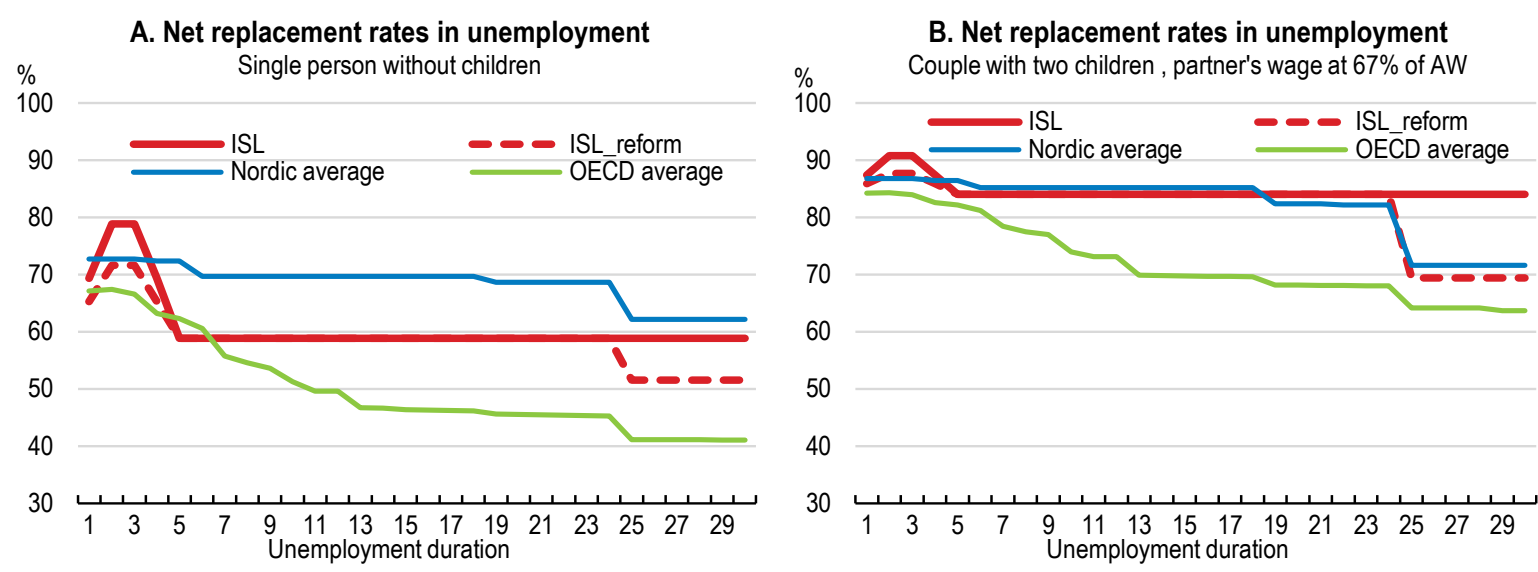

C. Effective tax rate on entering employment
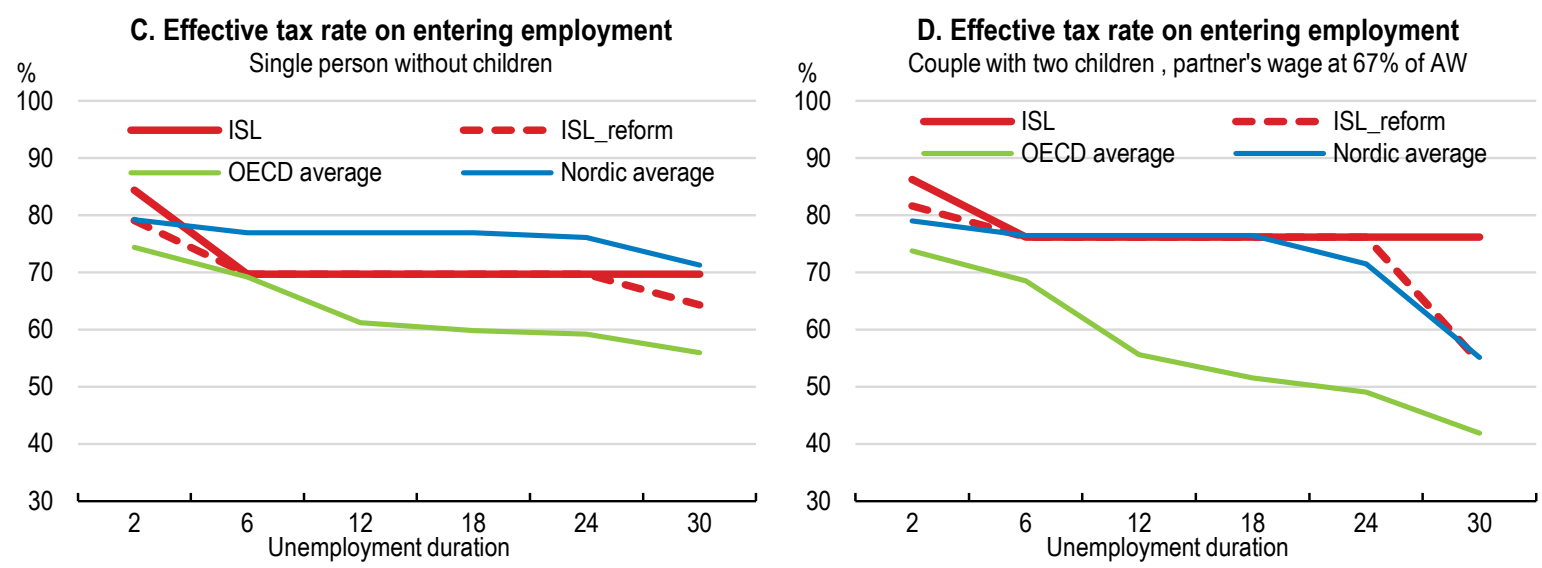

\section{E. Effective tax rate on entering employment} Duration of unemployment 2 months
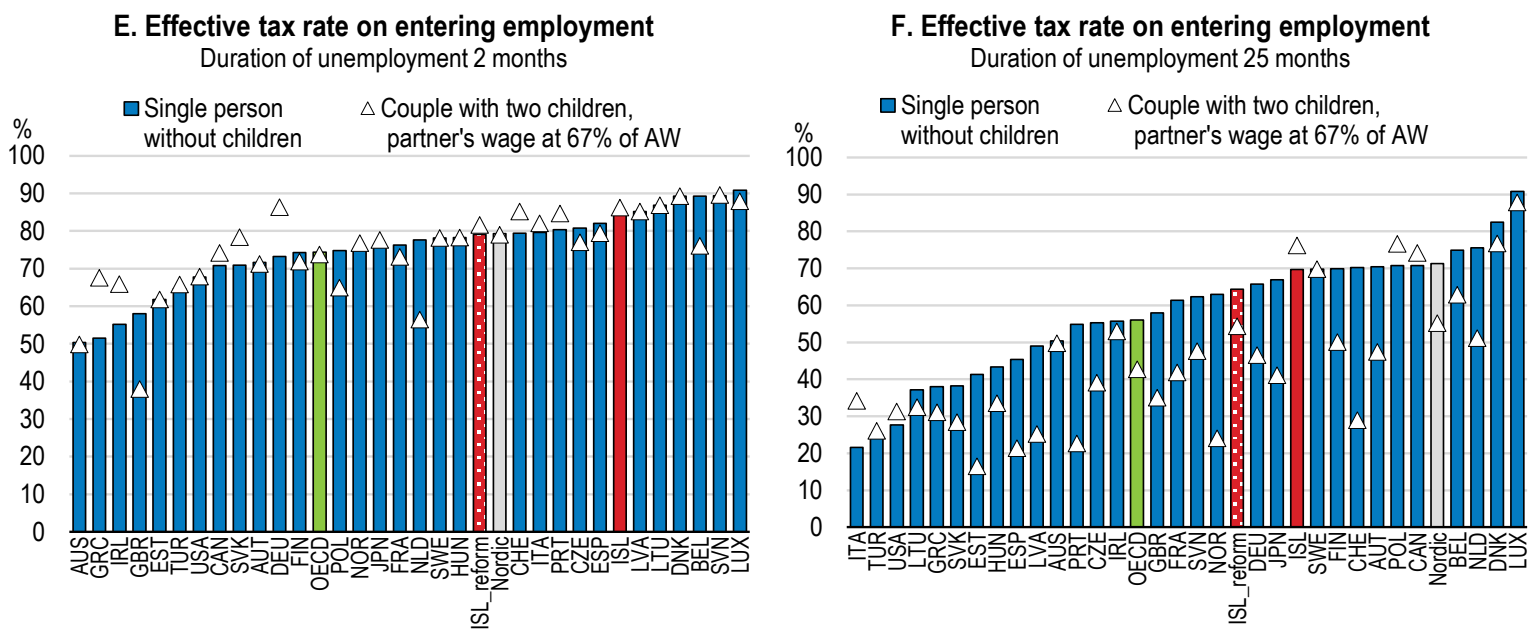

Note: Net Replacement Rates in unemployment measure the proportion of previous in-work income that is maintained after 1, 2, .., T months of unemployment. Nordic average includes Denmark, Finland, Norway and Sweden. Results refer to a 40-years-old unemployed person with a "long" and continuous contribution history and previous earnings at $67 \%$ of the average wage. For couples, the spouse is employed at $67 \%$ of average wage. Children are 4 and 6 years old. Details of the reform are explained in Box 4.

Source: OECD, Tax-Benefit model, 2018.

StatLink त्गाड़ https://doi.org/10.1787/888933996847 
Compared with similar schemes in other Nordic and OECD countries, the duration of unemployment benefit in Iceland is relatively long (Table 1). In the first three months of the entitlement the benefit is related to previous earnings, while for the remaining 27 months it is paid on a flat-rate basis. Despite the relatively long duration, entitlements are not means tested. This implies that jobseekers with different family and labour market backgrounds receive the same amount after the initial three-month period that the benefit is income-linked and until the expire date (Figure 22). Moreover, unemployment benefits can be accessed relatively easily: claimants in Iceland are required to be employed for only 3 months before the benefit receipt, compared to an OECD average of approximately 10 months (Table 1). The strictness of behavioural requirements for maintaining eligibility is, however, in line with the OECD average (Immervoll and Knotz, 2018 [50] ).

Table 1. Unemployment insurance benefit (UI) provisions in selected countries

\begin{tabular}{lccc}
\hline & $\begin{array}{c}\text { Minimum } \\
\text { employment } \\
\text { requirement for UI } \\
\text { benefit entitlement } \\
\text { (months) }\end{array}$ & $\begin{array}{c}\text { Strictness of behavioural } \\
\text { requirements to maintain } \\
\text { eligibility }\end{array}$ & $\begin{array}{c}\text { Maximum duration } \\
\text { of regular UI } \\
\text { benefits } \\
\text { (months) }\end{array}$ \\
Denmark & 12 & 1.14 & 24 \\
Finland & 6 & 0.91 & 19 \\
Iceland & 3 & 1.02 & 30 \\
Norway & -- & 1.02 & 24 \\
Sweden & 6 & 1.12 & 14 \\
OECD average & 10 & 1.04 & 14 \\
\hline
\end{tabular}

Note: The OCED average is calculated as an arithmetic mean of the scores. Instead of the minimum employment requirement, Norway has a minimum requirement with respect to previous earnings. The "strictness" indicator encompasses availability for taking up a job, monitoring and sanctions sub-indicators.

Source: OECD tax-benefit comparative tables and OECD Employment Outlook 2018, Figure 5.7, OECD Publishing, Paris.

An investigation of the potential impact of the current unemployment benefit scheme on work incentives would be advisable. If deemed necessary, some parameters of the unemployment scheme, such as replacement rates, maximum duration and minimum employment eligibility requirements (Table 1), could be brought more into line with international practice, while addressing equity trade-offs. For example, OECD analysis carried out in the context of this Survey suggests that bringing the net replacement rates of unemployment benefits closer to the OECD average would increase incentives to work for low paid workers, especially in the case of long-term unemployed with a working spouse and young children (Box 4) (Figure 22).

An alternative (or complementary) reform is to introduce earnings disregards in the means test of the social assistance programme, and partial withdrawal of unemployment benefit entitlements for those who take up full-time work at low earnings, or temporary earnings disregards for those who take up full-time work at higher earnings. Such reform would increase the net household income for those who move into work, but would not change the net replacement rates in unemployment. A number of countries are implementing income disregards in their social assistance programmes, including Finland, Portugal, the Slovak Republic, and more recently Lithuania (OECD, 2018[51]). 


\section{Box 4. Potential impact of reforms of out-of-work benefits on work incentives in Iceland}

The present analysis, based on the OECD tax-benefit model for Iceland, attempts to investigate the potential impact of reforms that would bring net replacement rates (NRRs) in unemployment closer to OECD average on the financial incentives to work among low paid workers.

The reform scenario adjusts the replacement rates of unemployment insurance benefit ("Atvinnuleysisdagpeningar") in the beginning of the unemployment spell (the first 3 months) in line with the Nordic and OECD averages. This implies a reduction of $10 \%$. It also assumes a maximum duration of unemployment insurance benefit of 24 months, instead of 30 currently, similar to the practice in other Nordic countries. The latter allows for an earlier move of the jobseeker from unemployment insurance scheme, which is not means-tested and fully withdrawn for those who take up full-time work, to a more flexible social assistance programme (municipality financial assistance, "Fjárhagsaðstoð sveitarfélaga"), that involves a more gradual withdrawal rate with respect to in-work earnings and, therefore, provides, higher incentives to work.

In the reform scenario, the social assistance programme enters with a slightly lower amount for families without children, which brings the structure of the programme closer to the standard OECD practices, where benefit amounts increase with the family size ${ }^{1}$. Nevertheless, the generosity of the social assistance programme in Iceland remains among the highest in the OECD even after this hypothetical reform.

The combined effect of the above reforms is net replacement rates in unemployment closer to the OECD average and higher work incentives to take up employment (Figure 22). The extent of the increase in work incentives depends on the family and labour market circumstances. Incentives are particularly higher for low-paid workers with long unemployment durations.

1. OECD tax-benefit model assumes the amounts of social assistance for Reykjavik. Amounts can be lower in other municipalities. The model includes only regular benefit payments. Additional support granted on a caseby-case basis is not taken into account.

Source: OECD tax-benefit model

\section{Making better use of immigrant skills}

A comprehensive strategy to foster strong and relevant skills should ensure the best use of immigrant skills. Immigrants make up a growing share of the Icelandic population, accounting for $14 \%$ of total population in 2017 , compared to an OECD total of $10 \%$ (OECD, 2018 ${ }_{[52]}$ ). Nevertheless, a much larger proportion of immigrants, especially nonEU born, are overqualified compared to native workers, implying that many of these workers do not manage to translate higher overall education levels into better labour market outcomes (Figure 23). In addition, while overall employment rates for immigrant and nonimmigrant workers do not differ much, the former group underperforms when looking at the highly-educated workers. All these suggest that there is scope for making better use of immigrant skills. At the same time, regulations for the employment of workers outside the European Economic Area (EEA) are tight, with scope for more open markets for services trade through the temporary movements of non-EEA workers according to OECD Trade Restrictiveness Index (OECD, 2018 $8_{[53]}$ ). This would help Iceland to meet needs in growing sectors, for instance, information technology. 
Figure 23. Immigrant integration in the labour market could be strengthened
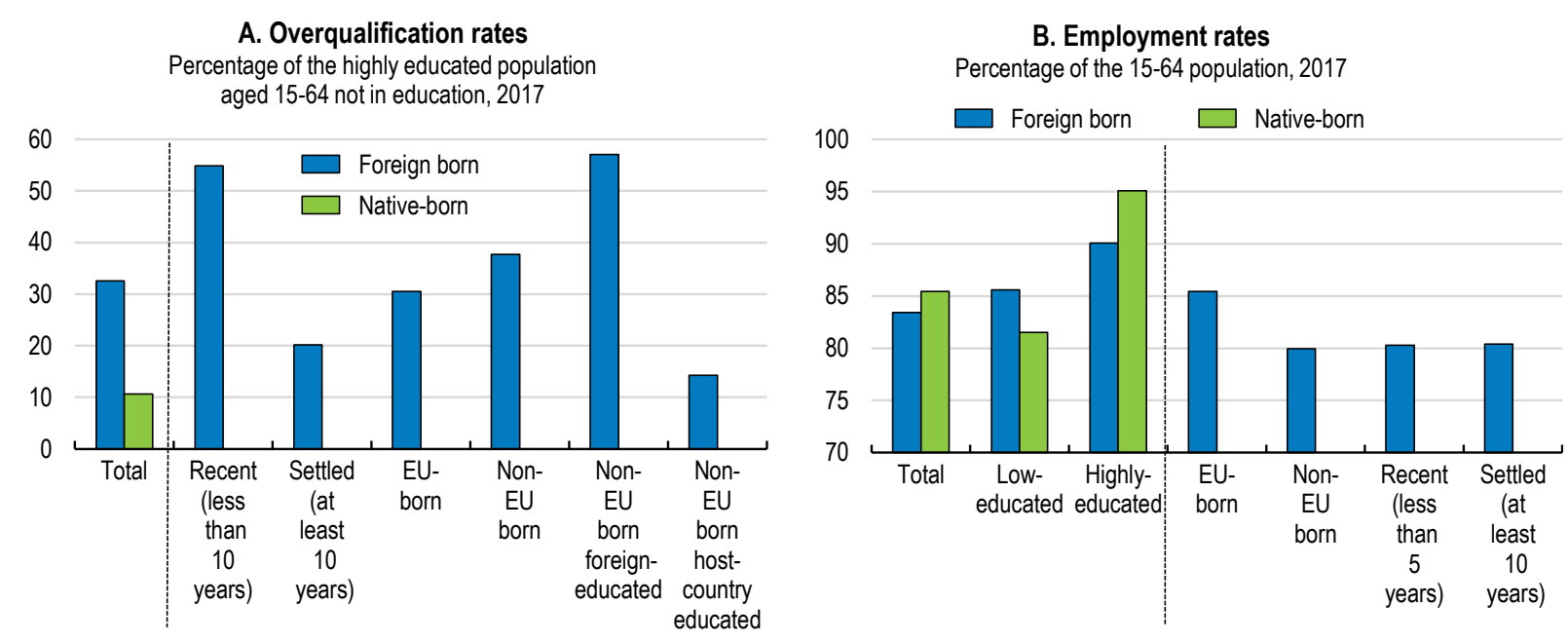

Source: OECD, "Settling In 2018: Main Indicators of Immigrant Integration".

StatLink त्गाजम https://doi.org/10.1787/888933996866

In the above context, there is much merit in focusing policy action on improving recruitment modalities for immigrant workers, including through mentoring and language programmes, as well as assessment and recognition of foreign qualifications (OECD, $\left.2019_{[39]}\right)$. As a step forward, the 2016-2019 Action Plan for Immigrants aims to improve the education status and labour market integration of immigrant workers in Iceland including through the introduction of quality criteria for language classes and a simplification of the assessment process of immigrants' educational qualifications, as well as increased opportunities for continuing education and vocational training for immigrant workers. These measures need to be complemented by well-designed immigration rules to ensure that the skills attracted from abroad correspond closely to domestic labour market needs. In turn, this hinges upon systematic skills assessment and anticipation exercises that Iceland is currently developing, setting the foundations for stronger skills policies. 
Findings and recommendations to foster strong and relevant skills

\begin{tabular}{|c|c|}
\hline \multicolumn{2}{|r|}{ Promoting skills } \\
\hline $\begin{array}{l}\text { Educational performance remains weak, with many } \\
\text { students lacking strong core skills at the end of } \\
\text { compulsory education. The score is lower among } \\
\text { immigrant children }\end{array}$ & $\begin{array}{l}\text { Improve teaching quality by extending the period of practical training in } \\
\text { initial education programmes and by providing more custom-made } \\
\text { opportunities for teachers' professional development } \\
\text { Offer effective language training programmes }\end{array}$ \\
\hline $\begin{array}{l}\text { The analysis and forecasting of skills needs has not been } \\
\text { conducted on a systematic basis to inform policy decision }\end{array}$ & $\begin{array}{l}\text { Develop methods and tools for monitoring skills needs that rely on several } \\
\text { information sources, preferably both quantitative and qualitative }\end{array}$ \\
\hline $\begin{array}{l}\text { Skills shortages and qualification mismatch weigh on } \\
\text { productivity growth }\end{array}$ & $\begin{array}{l}\text { Strengthen vocational skills by better integrating work-and school-based } \\
\text { training } \\
\text { Link university funding partially to the success of tertiary courses in } \\
\text { providing skills corresponding to labour market needs }\end{array}$ \\
\hline \multicolumn{2}{|c|}{ Ensuring strong core skills at the end of compulsory education } \\
\hline Student skills are declining & $\begin{array}{l}\text { Strengthen literacy as a separate subject in school curricula for higher grades } \\
\text { Establish minimal credit hours for pre-service class-based practice of teachers }\end{array}$ \\
\hline $\begin{array}{l}\text { The mechanisms for monitoring education outcomes are not } \\
\text { sufficiently effective }\end{array}$ & $\begin{array}{l}\text { Develop an effective system of teacher appraisal } \\
\text { Increase the frequency and school coverage of external evaluations }\end{array}$ \\
\hline \multicolumn{2}{|c|}{ Tackling skills imbalances } \\
\hline $\begin{array}{l}\text { The vocational education and training (VET) system is } \\
\text { complex and lacks strong co-ordination, with scope to } \\
\text { enhance its labour-market relevance }\end{array}$ & $\begin{array}{l}\text { Re-assess the functions of the numerous occupational committees and } \\
\text { streamline VET programmes based on a well-evidenced assessment } \\
\text { Introduce opportunities for workplace learning to all vocational programmes } \\
\text { Strengthen work-based training, including by linking the length of } \\
\text { apprenticeships to the level of the acquired competences }\end{array}$ \\
\hline $\begin{array}{l}\text { Tertiary education is more input- than output-oriented and } \\
\text { does not provide sufficient vocational skills. Research- } \\
\text { business collaboration on innovation is weak }\end{array}$ & $\begin{array}{l}\text { Introduce multi-year performance agreements between the government and } \\
\text { each higher-education institution } \\
\text { Provide more vocational skills at tertiary education level through an evaluation of } \\
\text { the costs and benefits of potential reform options } \\
\text { Give more weight to collaborative research when allocating funds to tertiary } \\
\text { institutions }\end{array}$ \\
\hline $\begin{array}{l}\text { Less educated workers participate less in lifelong learning } \\
\text { programmes }\end{array}$ & $\begin{array}{l}\text { Encourage participation in adult learning of under-represented groups, including } \\
\text { through well-designed financial incentives }\end{array}$ \\
\hline \multicolumn{2}{|c|}{ Use existing skills more effectively } \\
\hline $\begin{array}{l}\text { The Public Employment Services lacks well-developed } \\
\text { performance indicators and is not yet fully digitalised }\end{array}$ & $\begin{array}{l}\text { Proceed with the modernisation of Public Employment Services setting as } \\
\text { priority the development of high-quality key performance indicators }\end{array}$ \\
\hline $\begin{array}{l}\text { Net replacement rates in unemployment are high, especially } \\
\text { for low paid workers }\end{array}$ & $\begin{array}{l}\text { Reform the key parameters of the unemployment benefits system, for instance } \\
\text { replacement rates, maximum duration and minimum employment eligibility } \\
\text { requirements, if this is deemed necessary to boost work incentives }\end{array}$ \\
\hline Immigrant skills can be integrated better in the labour market & $\begin{array}{l}\text { Ensure effective mentoring and language programmes for immigrants and } \\
\text { improved assessment and recognition of foreign qualifications }\end{array}$ \\
\hline
\end{tabular}




\section{References}

Andersen, T., K. Hougaard and S. Ólafsson (2011), Assessment of the Labour Market in Iceland, Danish Technological Institute.

Brogi, L. and V. Koutsogeorgopoulou (forthcoming), Analysing the Determinants of PISA Outcomes for Iceland.

Directorate of Education (2017), Results of the Lesferill Reading Fluency Tests, September.

Echazarra, A. and T. Radinger (2019), "Learning in Rural Schools: Insights from PISA, TALIS and the Literature", OECD Education Working Papers, No. 196, OECD Publishing, Paris, https://dx.doi.org/10.1787/8b1a5cb9-en.

European Agency (2017), Education for All in Iceland: External Ausdit of the Icelandic System for Inclusive Education.

European Commission (2019), European Network of Public Employment Services - Anual Report 2018, European Union.

European Commission (2018), Benchlearning Initiative External Assessment, Summary Report 2nd Cycle-Iceland, European Public Emplyment Services (PES) Network.

European Commission (2017), European Innovation Scoreboard.

European Commission (2015), The Teaching Profession in Europe: Practices, Perceptions and Policies, Eurycide Report, https://publications.europa.eu/en/publication-detail/ppublication/4b77775b-6d06-11e5-9317-01aa75ed71a1.

Immervoll, H. and C. Knotz (2018), "How Demanding are Activation Requirements for Jobseekers", OECD Social, Employment and Migration Working Papers, No. 215, OECD Publishing, Paris, https://dx.doi.org/10.1787/2bdfecca-en.

Institute of Economic Studies (2018), Analysis of the Relation Between Education, Occupations and Industry Sectors, (in Icelandic).

Jorgensen, C. (2015), Challenges for Worked-Based Learning in Vocational Education and Training in the Nordic Countries, in Bohlinger, S. et al. (eds.), Working and Learning in Times of Uncertainty, 159-201, Sense Publisher.

Kavli, A. (2018), TIMSS and PISA in the Nordic Countries, in Northern Lights on TIMSS and PISA 2018, Nordic Council of Ministers, http://dx.doi.org/10.6027/TN2018-524.

Ministry of Education, Science and Culture (2014), Review of Policies to Improve the Effectiveness of Resource Use in Schools Country Background Report Iceland.

Musset, P. and R. Valle (2013), A Skills Beyond School Commendary on Iceland, OECD Pubslishing, Paris. 
Nissinen, K. et al. (2018), The Urban Disadvantage in Education? Science Achievement Differences Between Metropolitan and Other Areas in Finland and Iceland in PISA 2015, in Northen Lights on TIMSS and PISA 2018, Nordic Council of Ministers, http://dx.doi.org/10.6027/TN2018-524.

OECD (2019), A Flying Start: Improving Initial Teacher Preparation Systems, OECD Publishing, Paris, https://dx.doi.org/10.1787/cf74e549-en.

OECD (2019), OECD Employment Outlook 2019: The Future of Work, OECD Publishing, Paris, https://dx.doi.org/10.1787/9ee00155-en.

OECD (2019), OECD Skills Strategy 2019: Skills to Shape a Better Future, OECD Publishing, Paris, https://dx.doi.org/10.1787/9789264313835-en.

OECD (2019), OECD Skills Strategy Flanders: Assessment and Recommendations, OECD Skills Studies, OECD Publishing, Paris, https://dx.doi.org/10.1787/9789264309791-en.

OECD (2018), Education at a Glance 2018: OECD Indicators, OECD Publishing, Paris, https://dx.doi.org/10.1787/eag-2018-en.

OECD (2018), Effective Teacher Policies: Insights from PISA, PISA, OECD Publishing, Paris, https://dx.doi.org/10.1787/9789264301603-en.

OECD (2018), Getting Skills Right: Australia, Getting Skills Right, OECD Publishing, Paris, https://dx.doi.org/10.1787/9789264303539-en.

OECD (2018), OECD Economic Surveys: Lithuania, OECD Pablishing, Paris.

OECD (2018), OECD Services Trade Restrictiveness Index (STRI): Iceland.

OECD (2018), Reviews of Labour Market and Social Policies: Lithuania, OECD Publishing, Paris.

OECD (2018), Settling In 2018: Main Indicators of Immigrant Integration.

OECD (2017), OECD Economic Surveys: Australia 2017, OECD Publishing, Paris, https://dx.doi.org/10.1787/eco_surveys-aus-2017-en.

OECD (2017), OECD Economic Surveys: Switzerland 2017, OECD Publishing, Paris, https://dx.doi.org/10.1787/eco surveys-che-2017-en.

OECD (2016), Economic Surveys: Norway 2016, OECD Publishing, Paris, https://doi.org/10.1787/eco surveys-nor-2016-en.

OECD (2016), Education Policy Outlook: Iceland, OECD, Paris.

OECD (2016), Getting Skills Right: Assessing and Anticipating Skill Needs, OECD Publishing, Paris. 
OECD (2016), PISA 2015 Results (Volume I): Excellence and Equity in Education, PISA, OECD

Publishing, Paris, https://dx.doi.org/10.1787/9789264266490-en.

OECD (2016), PISA 2015 Results (Volume II): Policies and Practices for Successful Schools, PISA, OECD Publishing, Paris, https://dx.doi.org/10.1787/9789264267510-en.

OECD (2015), Economic Surveys: Sweden 2015, OECD Publishing, Paris.

OECD (2015), Helping Immigrant Students to Succeed at School - and Beyond, OECD Publsihing, Paris.

OECD (2015), The ABC of Gender Equality in Education: Aptitude, Behaviour, Confidence, PISA, OECD Publishing, Paris, https://dx.doi.org/10.1787/9789264229945-en.

OECD (2015), The Innovation Imperative: Contributing to Productivity, Growth and WellBeing, OECD Publishing, Paris, https://dx.doi.org/10.1787/9789264239814-en.

OECD (2014), Education at a Glance 2014: OECD Indicators, OECD Publishing, Paris, https://dx.doi.org/10.1787/eag-2014-en.

OECD (2014), TALIS 2013 Results: An International Perspective on Teaching and Learning, TALIS, OECD Publishing, Paris, https://dx.doi.org/10.1787/9789264196261-en.

OECD (2013), “Teacher Appraisal: Enhancing Teacher Professionalism”, in Synergies for Better Learning: An International Perspective on Evaluation and Assessment, OECD Publishing, Paris, https://dx.doi.org/10.1787/9789264190658-9-en.

OECD (2012), Towards a Strategy to Prevent Dropout in Iceland, OECD-Iceland Improving Schools Review, OECD Publishing, Paris, http://www.oecd.org/iceland/49451462.pdf.

OECD (2011), Economic Surveys: Iceland, OECD Publishing, Paris.

OECD (2010), Innovation Vouchers, OECD Innovation Platform, http://www.oecd.org/innovation/policyplatform.

OECD (2009), Review on Evaluation and Assessment Frameworks for Improving School Outcomes: Common Policy Challenges, Issues Note, Education and Training Policies.

OECD (2005), Teachers Matter: Attracting, Developing and Retaining Effective Teachers, Education and Training Policy, OECD Publishing, Paris, https://dx.doi.org/10.1787/9789264018044-en.

OECD (forthcoming), Human Resources in School Education [working title], OECD Reviews of School Resources, OECD Publishing, Paris, http://www.oecd.org/education/school/thematiccomparativereports.htm.

Rögnvaldsson, E. et al. (2018), Icelandic in the Digital Age, Meta-Net Springer.

Sigbórsson, R. (2017), Testing or Transforming Practice: Probing an Icelandic National Initiative to Improve Literacy Education, Literacy Vol. 51, No. 2, May. 
Statistics Iceland (2018), Educational Attainment of Women and Men Differs by Region, Statistics Iceland, March 8., http://www.statice.is/publications/news-archive/socialaffairs/women-and-men-in-iecaland-2018/.

Steafansdottir, D. (2014), Apprenticeship-type Schemes and Structure Work-based Learning Programmes: Iceland, CEDEFOP.

Steinpórsdóttir, F. et al. (2016), Gender Budgeting in Academia, GARCIA Working Papers No. 8. University of Trento (ISBN 978-88-8443-675-7).

The Icelandic National Audit Office (2008), The Local Government's Equalisation Fund and the Primary School. Performance Audit (summary in English). 